\title{
The water column distribution of carbonate system variables at the ESTOC site from 1995 to 2004
}

\author{
M. González-Dávila ${ }^{1}$, J. M. Santana-Casiano ${ }^{1}$, M. J. Rueda ${ }^{2}$, and O. Llinás ${ }^{2}$ \\ ${ }^{1}$ Departamento de Química, Facultad de Ciencias del Mar, Universidad de Las Palmas de Gran Canaria, 35017 Las Palmas de \\ Gran Canaria, Spain \\ ${ }^{2}$ Instituto Canario de Ciencias Marinas, Gobierno de Canarias, Las Palmas de Gran Canaria, Spain
}

Received: 10 March 2010 - Published in Biogeosciences Discuss.: 18 March 2010

Revised: 27 September 2010 - Accepted: 5 October 2010 - Published: 11 October 2010

\begin{abstract}
The accelerated rate of increase in atmospheric carbon dioxide and the substantial fraction of anthropogenic $\mathrm{CO}_{2}$ emissions absorbed by the oceans are affecting the anthropocenic signatures of seawater. Long-term time series are a powerful tool for investigating any change in ocean bio-geochemistry and its effects on the carbon cycle. We have evaluated the ESTOC (European Station for Time series in the Ocean at the Canary islands) observations of measured $\mathrm{pH}$ (total scale at $25^{\circ} \mathrm{C}$ ) and total alkalinity plus computed total dissolved inorganic carbon concentration $\left(\mathrm{C}_{\mathrm{T}}\right)$ from 1995 to 2004 for surface and deep waters, by following all changes in response to increasing atmospheric carbon dioxide. The observed values for the surface partial pressure of $\mathrm{CO}_{2}$ from 1995 to 2008 were also taken into consideration. The data were treated to better understand the fundamental processes controlling vertical distributions in the Eastern North Atlantic Ocean and the accumulation of anthropogenic $\mathrm{CO}_{2}, C_{\mathrm{ANT}} . C_{\mathrm{T}}$ at constant salinity, $N C_{\mathrm{T}}$, increased at a rate of $0.85 \mu \mathrm{mol} \mathrm{kg}{ }^{-1} \mathrm{yr}^{-1}$ in the mixed layer, linked to an $f \mathrm{CO}_{2}$ increase of $1.7 \pm 0.7 \mu \mathrm{atm} \mathrm{\textrm {yr } ^ { - 1 }}$ in both the atmosphere and the ocean. Consequently, the mixed layer at ESTOC site has also become more acidic, $-0.0017 \pm 0.0003$ units $\mathrm{yr}^{-1}$, whereas the carbonate ion concentrations and $\mathrm{CaCO}_{3}$ saturation states have also decreased over time. $\mathrm{NC}_{\mathrm{T}}$ increases at a rate of $0.53,0.49$ and $0.40 \mu \mathrm{mol} \mathrm{kg}^{-1} \mathrm{yr}^{-1}$ at 300,600 , and $1000 \mathrm{~m}$, respectively. The general processes controlling the vertical variations of alkalinity and the inorganic carbon distribution were computed by considering the pre-formed values, the production/decomposition of organic matter and the formation/dissolution of carbonates. At $3000 \mathrm{~m}, 30 \%$ of the inorganic carbon production is related to the dissolution
\end{abstract}

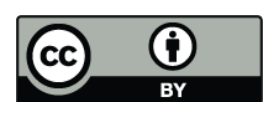

Correspondence to:

M. González-Dávila

(mgonzalez@dqui.ulpgc.es) of calcium carbonate, increasing to $35 \%$ at $3685 \mathrm{~m}$. The total column inventory of anthropogenic $\mathrm{CO}_{2}$ for the decade was $66 \pm 3 \mathrm{~mol} \mathrm{~m}^{-2}$. A model fitting indicated that the column inventory of $C_{\mathrm{ANT}}$ increased from $61.7 \mathrm{~mol} \mathrm{~m}^{-2}$ in the year 1994 to $70.2 \mathrm{~mol} \mathrm{~m}^{-2}$ in 2004 . The ESTOC site is presented as a reference site to follow $C_{\mathrm{ANT}}$ changes in the Northeast Atlantic Sub-tropical gyre.

\section{Introduction}

Atmospheric carbon dioxide $\left(\mathrm{CO}_{2}\right)$ levels have increased by nearly $40 \%$, from the pre-industrial levels of around 280 ppmv (parts per million volume) to $384 \mathrm{ppmv}$ in 2007 (Solomon et al., 2007). The increase in atmospheric $\mathrm{CO}_{2}$ is buffered by oceanic uptake which accounts for nearly one third of the anthropogenic carbon added to the atmosphere (Sabine et al., 2004). However, the ocean $\mathrm{CO}_{2}$ uptake produces alterations in fundamental chemical balances including the $\mathrm{pH}$, carbonate ion concentration and calcite and aragonite saturation, that together are commonly referred to as "ocean acidification". As this process on its own is independent of any climate change, and reductions in $\mathrm{CO}_{2}$ emissions will not reduce ocean acidification, the expression "the other $\mathrm{CO}_{2}$ problem" has been coined to refer to the new phenomenon (Turley, 2005).

The concern about the long-term fate of anthropogenic $\mathrm{CO}_{2}$ in the atmosphere and the ocean has made us reexamine the fundamental processes controlling the distributions of dissolved inorganic carbon $\left(C_{\mathrm{T}}\right)$ and total alkalinity $\left(A_{\mathrm{T}}\right)$ in oceans. Long-term time series are a powerful tool for investigating any change in ocean bio-geochemistry and its effects on the carbon cycle. They are also the most direct way of estimating the accumulation of anthropogenic $\mathrm{CO}_{2}$ in the

Published by Copernicus Publications on behalf of the European Geosciences Union. 


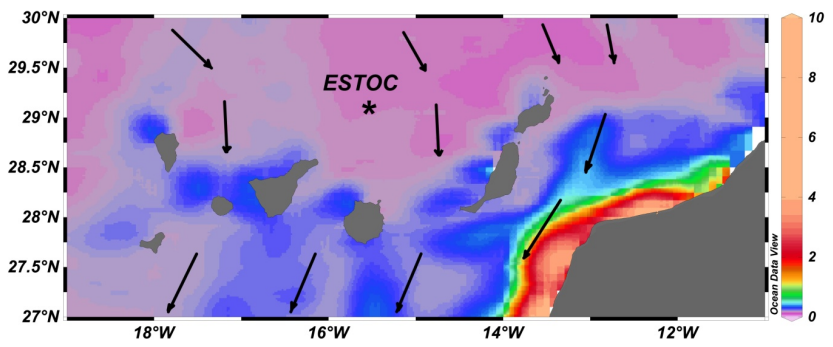

Fig. 1. Location of the ESTOC site $\left(29^{\circ} 10^{\prime} \mathrm{N}, 15^{\circ} 30^{\prime} \mathrm{W}\right)$ and the Canary Islands in the Eastern North Atlantic on a satellite image (chlorophyll a in $\mathrm{mg} \mathrm{m}^{-3}$ ) from 19 March 2000 for the area and with indication of the The Canary current, the southwestward flow component of the North Atlantic subtropical gyre (http://oceancurrents.rsmas.miami.edu/atlantic/canary.html).

oceans. There are several long-term ocean time series observations of seawater $\mathrm{CO}_{2}$ that have allowed the evaluation of inter-annual trends of surface seawater $\mathrm{CO}_{2}$ and air-sea $\mathrm{CO}_{2}$ fluxes. They include (1) BATS (the Bermuda Atlantic Time series Study) and the Hydrostation $\mathrm{S}$ station located near Bermuda in the NW Atlantic Ocean (e.g., Bates et al., 1996, 2001); (2) the Hawaii Ocean Time series station, HOT, located at ALOHA near Hawaii in the North Pacific Ocean (e.g., Keeling et al., 2004; Brix et al., 2004); (3) the ESTOC site (European Station for Time series in the Ocean, the Canary Islands), located off the Canary Islands in the NE Atlantic Ocean (e.g., Gonzalez-Dávila et al., 2003; SantanaCasiano et al., 2007;); (4) The IC-ts, Iceland Sea time series, in the North of Iceland (e.g. Olafsson et al., 2009, 2010); (5) The weather-ship station M, located in the Norwegian Sea (e.g. Gislefoss et al. 1998; Skjelvan et al., 2008); (6) the South East Asia time-series Study site (SEATS) in the northern South China Sea (e.g. Chou et al., 2005, 2007); (7) Ocean Weather Station P/line P in the North-East Pacific (Wong et al., 1999), and (8) the Kyodo North Pacific Ocean Time series (KNOT) in the western North Pacific sub-polar region (Tsurushima et al., 2002; Wakita et al., 2005).

The factors driving seasonal and inter-annual variability in surface or oceanic mixed layers for each oceanic time-series station have been totally covered in the aforementioned references for $C_{\mathrm{T}}, A_{\mathrm{T}}$, together with the oceanic partial pressure of $\mathrm{CO}_{2}$ (expressed as fugacity, $f \mathrm{CO}_{2}$ ). Few works have focused on the surface $\mathrm{pH}$ variability at these sites (Bates, 2007; Santana-Casiano et al., 2007; Dore et al., 2009). Only Dore et al. (2009) at the HOT site focused on $\mathrm{pH}$ trends in the sub-surface waters and how they vary with depth, using both observed and computed $\mathrm{pH}_{\mathrm{T}}\left(C_{\mathrm{T}}, A_{\mathrm{T}}\right)$ values to prove the $\mathrm{pH}$ variability. To our knowledge, there is no other work that describes deep ocean trends not only from the perspective of $\mathrm{pH}$ but also for other related carbonate variables. It is commonly recognized that physical processes such as turbulent mixing, subduction, and advection, and transport of anthropogenic $\mathrm{CO}_{2}$ from the seasonally mixed layer into the ocean interior will alter the biogeochemical properties in deeper waters over time. The characterization of the changes produced requires significant vertical coverage of high accuracy, long-term data to be able to adequately resolve any observed changes.

The carbon dioxide variables determination at ESTOC was started in September 1995 with analyses of the spectrophotometric $\mathrm{pH}_{\mathrm{T}}, A_{\mathrm{T}}$ and $C_{\mathrm{T}}$ (after 2004) and $f \mathrm{CO}_{2}$ in surface seawater. The seasonal variability of the four carbon parameters for the surface water at ESTOC can be seen in previous studies by Santana-Casiano et al. (2007) whereas the factors contributing to the long-term variation observed in the mixed layer reported for the 1995-2004 period has also previously been published in González-Dávila et al. (2007). Here, we focused on the variations of the carbon system variables over time and over the full profile using data from 87 cruises at the ESTOC site and updating earlier estimates of the long-term surface $f \mathrm{CO}_{2}$. We examine the general processes controlling the vertical variations of $A_{\mathrm{T}}$ and $C_{\mathrm{T}}$, normalized to a constant salinity $N A_{\mathrm{T}}$ and $N C_{\mathrm{T}}$ below the surface mixed layer. The influence of anthropogenic $\mathrm{CO}_{2}$ in the water column has also been taken into consideration.

\section{Experimental section}

\subsection{The ESTOC site and sampling strategy}

The ESTOC site is positioned 60 miles North of the islands of Gran Canaria and Tenerife with a depth of $3685 \mathrm{~m}$ at $29^{\circ} 10^{\prime} \mathrm{N}, 15^{\circ} 30^{\prime} \mathrm{W}$ (Fig. 1). Monthly cruises were conducted by the Instituto Canario de Ciencias Marinas (ICCM) to monitor the variability over time of the biogeochemical parameters at the ESTOC from January 1994. From September 1995 , the carbon dioxide system $\mathrm{pH}$ variables in total scale at $25^{\circ} \mathrm{C}\left(\mathrm{pH}_{\mathrm{T}}\right)$, total alkalinity $\left(A_{\mathrm{T}}\right)$, the fugacity of $\mathrm{CO}_{2}$ in the atmosphere $\left(f \mathrm{CO}_{2, \text { air }}\right)$ and surface seawater $\left(f \mathrm{CO}_{2, \text { sw }}\right)$ were added to the monthly determinations of oxygen, nutrients and chlorophyll concentration. Over the years, the full profile was studied with the same periodicity although for logistics reasons only the first $1000 \mathrm{~m}$ were sampled in some periods (July-October 1996 and May-November 2000). From 2004 through to the present, the direct determination of total dissolved inorganic concentration $\left(C_{\mathrm{T}}\right)$ was also included in the sampling strategy.

\subsection{Hydrography}

The monthly sampling at ESTOC has been described in detail elsewhere (Llinás et al., 1999; González-Dávila et al., 2003). 5- and 10-L Niskin bottles were used to collect water samples. The samples for the carbon dioxide system determinations were taken after the oxygen samples and analyzed for $\mathrm{pH}_{\mathrm{T}}$ and alkalinity. The alkalinity samples $\left(C_{\mathrm{T}}\right.$ samples after 2004), if not analyzed on board, were fixed with saturated 
mercury chloride solution, the bottles sealed, and the samples analyzed on land before a week had elapsed. The continuous CTD data was calibrated from the water collected in discrete Niskin bottle samples for salinity using a calibrated Autosal $^{\mathrm{TM}}$ salinometer.

\subsection{The $\mathrm{pH}_{\mathrm{T}}$}

A system based on the spectrophotometric technique of Clayton and Byrne (1993) with m-cresol purple was used (González-Dávila et al., 2003). $\mathrm{CRMs}^{\mathrm{pH}} \mathrm{H}_{T}$ reading along years (batch \#34,\#42,\#46,\#49,\#50,\#64,\#70,\#74,\#78) gave a precision of \pm 0.0015 ( $n=15$ for each batch).

\subsection{Total alkalinity}

Samples for $A_{\mathrm{T}}$ were potentiometrically titrated with $\mathrm{HCl}$ to carbonic acid end point using two similar systems, described in detail by Mintrop et al. (2000). The titration of the different CRMs mentioned above (provided by A. Dickson at Scripps Institution of Oceanography) was used to test the performance of the titration system giving values with an accuracy of $\pm 1.5 \mu \mathrm{mol} \mathrm{kg}^{-1}$.

\subsection{Total dissolved inorganic carbon}

$C_{\mathrm{T}}$ was computed from the experimental values of the $\mathrm{pH}_{\mathrm{T}}$ and $A_{\mathrm{T}}$ using the carbonic acid dissociation constants of Mehrbach et al. (1973) as in Dickson and Millero (1987). The $C_{\mathrm{T}}\left(\mathrm{pH}_{\mathrm{T}}-A_{\mathrm{T}}\right)$ values were corrected using certified CRMs where the $\mathrm{pH}_{\mathrm{T}}$ and $A_{\mathrm{T}}$ had been previously determined. Any deviation on the certified CRMs values was corrected accordingly. The uncertainty associated to the resulting $C_{\mathrm{T}}\left(\mathrm{pH}_{\mathrm{T}}-A_{\mathrm{T}}\right)$ was $\pm 3 \mu \mathrm{mol} \mathrm{kg}{ }^{-1}$ ( $n=190$ along years). After 2004, a VINDTA 3C system (Mintrop et al., 2000) with coulometer determination was used with a substantially increased accuracy of $\pm 1.0 \mu \mathrm{mol} \mathrm{kg}^{-1}$ after CRMs titration (www.MARIANDA.com).

\subsection{Normalization to a constant salinity}

In order to remove the effects of evaporation and precipitation as well as a salinity-proportional parts of mixing/upwelling and a non-zero end-member on alkalinity and inorganic carbon concentration $\left(X_{\mathrm{T}}\right)$, the regional normalization to a constant salinity, $S^{\text {ref }}$, proposed by Friis et al. (2003) was applied instead of the traditional normalization $N X_{\mathrm{T}}=$ $X_{\mathrm{T}} / S^{\text {mea }} \cdot S^{\text {ref }}$. In this normalization, the salinity adjustment is based on a constant and region-specific term for $S=0$, which expresses river run off, upwelling from below the lysocline, calcification, and lateral sea surface water exchange.

$N X_{\mathrm{T}}=\left(X_{\mathrm{T}}^{\text {mea }}-X_{\mathrm{T}}^{S=0}\right) / S^{\text {mea }} \cdot S^{\mathrm{ref}}+X_{\mathrm{T}}^{S=0}$

Surface ESTOC data for $A_{\mathrm{T}}$ and $C_{\mathrm{T}}$ were fitted to the equation $X_{\mathrm{T}}=m_{\mathrm{T}} T+m_{S} S+b^{0}$,

$A_{\mathrm{T}}=0.2( \pm 0.16) T+56.61( \pm 3.27) S+321.79( \pm 76.3)$
$C_{\mathrm{T}}=-2.83( \pm 0.23) T+42.87( \pm 4.66) S+577.71( \pm 129.8)(3)$

with standard error of estimate of \pm 2.40 and \pm 3.42 for $A_{\mathrm{T}}$ and $C_{\mathrm{T}}$, respectively. According to Eqs. (2) and (3), $A_{\mathrm{T}}^{S=0}=321.79 \pm 76.3$ and $C_{\mathrm{T}}^{S=0}=577.71 \pm 129.8 . S^{\text {ref }}$ was fixed to the traditional salinity of 35 , even though this salinity is in the low salinity range of most Atlantic seawater. As indicated by Friis et al. (2003, 2007), regional salinity normalization for total alkalinity and inorganic carbon improves the interpretation of their variations in the water column.

\subsection{Experimental $\mathrm{fCO}_{2}$}

The $f \mathrm{CO}_{2}$ in air and in surface seawater was determined using a flow system similar to the one designed by Wanninkhof and Thoning (1993) and developed by F. J. Millero's group at the University of Miami. A differential, non-dispersive, infrared gas analyzer ( $\mathrm{LI}-6262 \mathrm{CO}_{2} / \mathrm{H}_{2} \mathrm{O}$ Analyzer) measured the concentration of $\mathrm{CO}_{2}$ in the air and in the equilibrated air samples. The system was calibrated for zero reading with pure nitrogen and by measuring two different standard gases (with mixed ratios of about 350 and $490 \mathrm{ppm} \mathrm{CO}_{2}$ in the air with accuracy to \pm 0.01 ) (NOAA), traceable to the World Meteorology Organization Scale. Our system had a precision of up to $\pm 1 \mu$ atm and was accurate for standard gases to $\pm 2 \mu \mathrm{atm}$. The fugacity of $\mathrm{CO}_{2}$ in seawater was calculated from the measured $x_{\mathrm{CO} 2}$. After 2005, the $f \mathrm{CO}_{2}$ in the air and in surface seawater was determined over the VOS-QUIMA line (www.carboocean.org) that passes 0.8 miles to ESTOC and described in detail in González-Dávila et al. (2009).

\subsection{Oxygen and nutrient determination}

The oxygen and nutrient analyses performed at the ICCM were described by Llinás et al. (1999). The precision for each set of five oxygen replicates was better than $2 \mu \mathrm{mol} \mathrm{kg}^{-1}$, and for each of the three replicates of nutrients was under 0.07 , 0.06 and $0.01 \mu \mathrm{mol} \mathrm{kg}^{-1}$ for silicate, nitrate and phosphate, respectively.

\section{Results and discussion}

\subsection{Water masses and Carbonate system distribution}

The ESTOC site is about 500 miles west of the NW African coast and 60 miles north of the Canary Islands (Fig. 1). It is far enough away from the coastal upwelling zone to be free of its influence, but the effects of upwelling filaments reaching the area have been described, thereby explaining inter-annual anomalies in surface-water properties (Santana-Casiano et al., 2007; González Dávila et al., 2007). The ESTOC site is located in the Sub-tropical Gyre and exhibits oligotrophic characteristics (Neuer et al., 2007). The circulation is driven by the southward-flowing Canary Current and the NE Trade Winds. A clear seasonality is, for instance, to be seen in the 

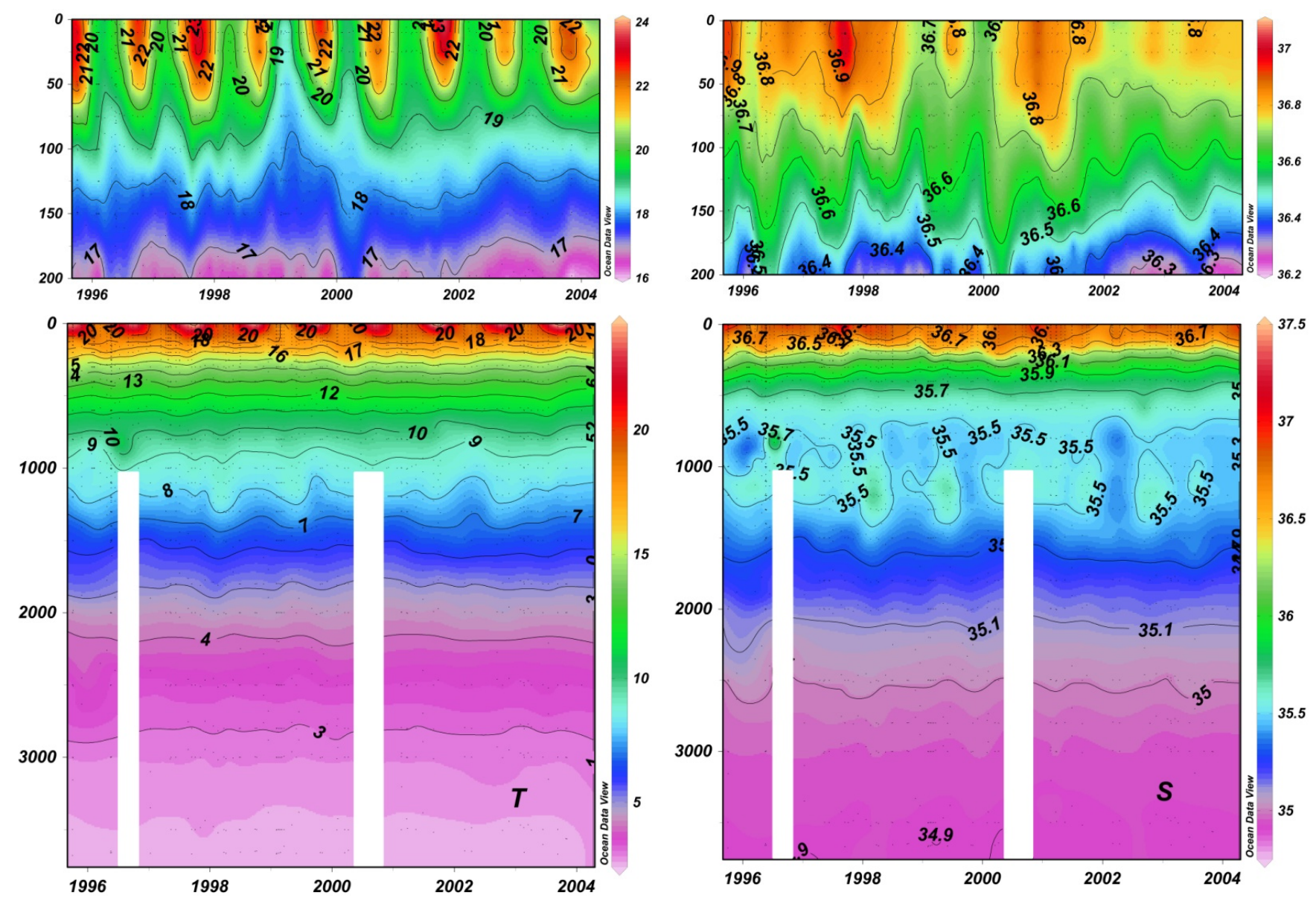

Fig. 2. Hovmöller diagram of water column temperature $\left({ }^{\circ} \mathrm{C}\right)$, salinity, $\mathrm{pH}$ in total scale at in situ conditions, $\mathrm{pH}_{\mathrm{Tis}}$, and $C_{\mathrm{T}}\left(\mu \mathrm{mol} \mathrm{kg}^{-1}\right)$ for the period from September 1995 to February 2004.

fact that the upper layer temperature reveals warming during the Summer season and cooling during Winter (Fig. 2). A high variability is observed in surface salinity, mainly due to the Trade Winds in Summer, which obscure a clear seasonal cycle (Santana-Casiano et al., 2007). The depth of the mixed layer (MLD) at the ESTOC varies, in general, between $20 \mathrm{~m}$ in the Summer to $150-200 \mathrm{~m}$ in the Winter (Cianca et al., 2007). The period of maximum mixed-layer depth is from February to April, with the deepest MLD occurring in 1996, 1999, and 2000.

A meticulous description of the water masses for the ESTOC area has been provided by Pérez et al. (2001) and Llinás et al. (2002) where the focus was on the distribution of salinity anomalies, and Cianca et al. (2007) and Machín et al. (2006), where mass fluxes were presented. Briefly, in the upper ocean of the ESTOC region, the two varieties of the Eastern North Atlantic Central Water (ENACW), ENACWt (Eastern North Atlantic Water of sub-tropical origin) and ENACWp (Eastern North Atlantic Water of sub-polar origin) are involved at different isopycnal levels. The upper salinity minimum centring at about $750 \mathrm{~m}$ depth is the lower end of the ENACW (Fig. 2). The ENACWt layer extends from the bottom of the surface layer down to $500 \mathrm{~m}$, following the 35.66 isohaline. Below this, there is a relatively narrow ENACWp layer. A minimum salinity of about 35.35 (at a temperature of around 7.5-8.5) has been observed in the time series, tracing the influence of the northward advection of the Antarctic Intermediate water, AAIW, as a poleward undercurrent of the Canary current, crossing the channels between the islands (Santana-Casiano et al., 2001). The modified Mediterranean water, MW, identified with the salinity maximum from $1100 \mathrm{~m}$ to $1200 \mathrm{~m}$ is a permanent feature in the area, with significant inter-annual variability as can be seen from the monitored values of salinity anomalies (Llinás et al., 2002; Cianca et al., 2007). Below the MW, a continuous decrease of salinity and temperature denotes the presence of North Atlantic deep water, NADW, detected by the scarce variability and linearity in the thermohaline structure.

The vertical distribution of water masses will also affect the carbonate system variable profiles. The $\mathrm{pH}_{\mathrm{T}}$ in situ conditions $\left(\mathrm{pH}_{\mathrm{T}, \text { is }}\right)$ at the ESTOC (Fig. 2) decrease with depth to a minimum at near 900-1000 m, roughly coincident 

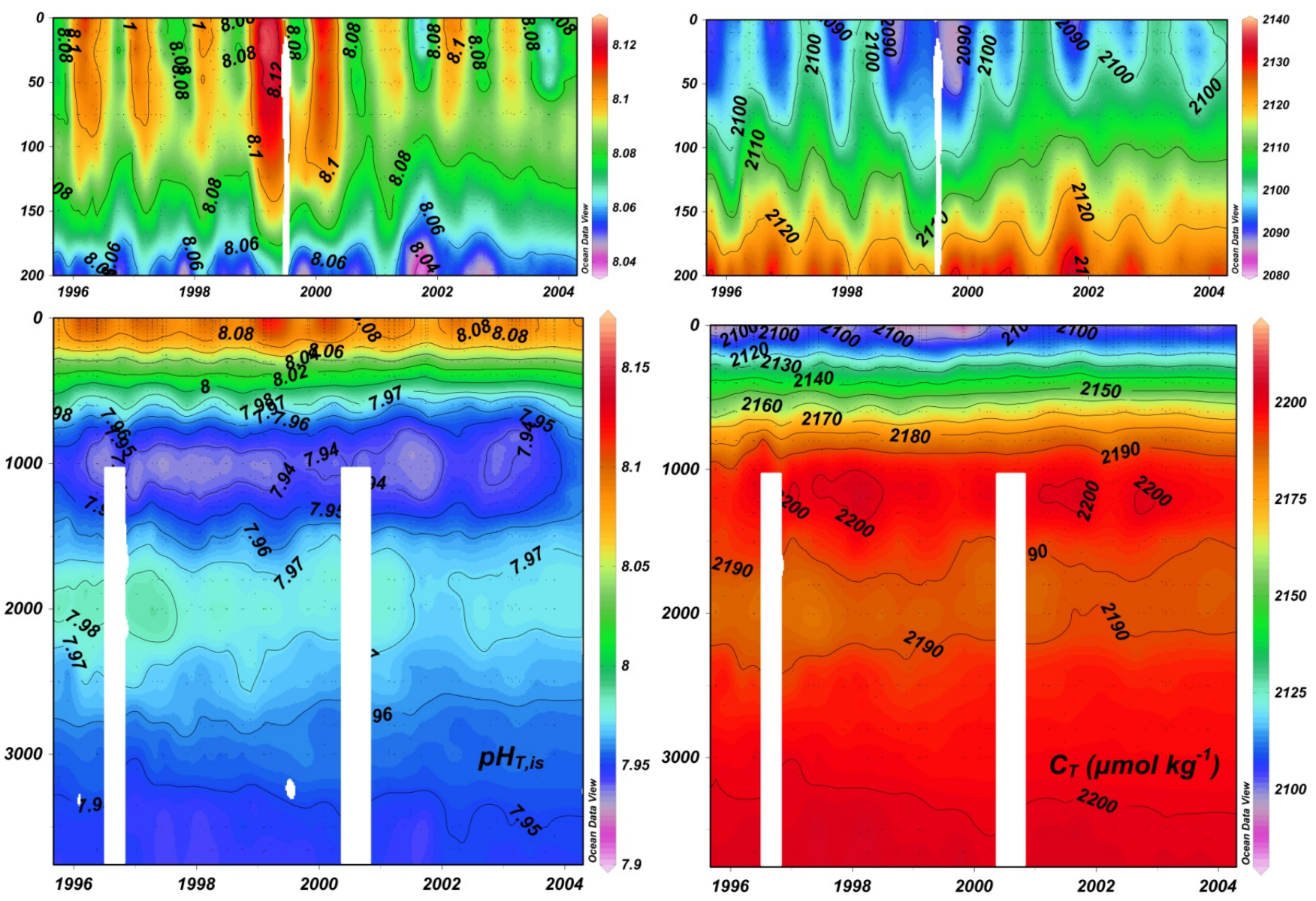

Fig. 2. Continued.

with the oxygen-minimum layer centered around 800-900 m (data not shown). The $\mathrm{pH}_{\mathrm{T}}$ at $25^{\circ} \mathrm{C}$, free from the effects of temperature variations on the carbonate equilibria, also decreases with depth from a value of around 7.95-7.97 at $200 \mathrm{~m}$ to $7.71-7.74$ at $1000 \mathrm{~m}$ (data not shown). This relatively high $\mathrm{pH}$ range at $1000 \mathrm{~m}$ evidences the effects of both low $\mathrm{pH}$ waters of Antarctic origin (Santana-Casiano et al., 2001) and Mediterranean waters with higher $\mathrm{pH}$ values. The $C_{\mathrm{T}}$ (also $N C_{\mathrm{T}}$ ) distribution increases with depth, reaching a maximum near $1000-1100 \mathrm{~m}$ (with values in the range of 2190 and $2200 \mu \mathrm{mol} \mathrm{kg}^{-1}$ for the $C_{\mathrm{T}}$ and 2170 and $2180 \mu \mathrm{mol} \mathrm{kg}^{-1}$ for the $N C_{\mathrm{T}}$ ), reflecting the impact of the organic matter re-mineralization. The $A_{\mathrm{T}}$ also decreases with depth, but with a distribution strongly related to salinity over the first $600 \mathrm{~m}$ in the ENACW region (data not shown).

Below $1000 \mathrm{~m}$, the $\mathrm{pH}_{\mathrm{T}}$ increases down through to $1500 \mathrm{~m}$ with values of around 7.75 for the $\mathrm{pH}_{\mathrm{T}, 25}$ and 7.97 at in situ conditions, related to both the Mediterranean water influence and to the balance between the effects of re-mineralization and carbonate dissolution. Below $1500 \mathrm{~m}$, the $\mathrm{pH}_{\mathrm{T} \text {,is }}$ decreases slightly down to 7.95 at the bottom, while the $\mathrm{pH}_{\mathrm{T}, 25}$ remains relatively constant at 7.73 . After the maxima close to $2210 \mu \mathrm{mol} \mathrm{kg}^{-1}$ when the highest Mediterranean water influences are traced by salinity maximum, the $C_{\mathrm{T}}$ decreases to values below 2190 at around $1500-1700 \mathrm{~m}$, increasing with depth to maximum values of $2202-2205 \mu \mathrm{mol} \mathrm{kg}^{-1}\left(N C_{\mathrm{T}}\right.$ $2206 \pm 1 \mu \mathrm{mol} \mathrm{kg}^{-1}$ at $3678 \mathrm{~m}$ ). The $A_{\mathrm{T}}$ (data not shown) increases from $2335 \pm 3 \mu \mathrm{mol} \mathrm{kg}{ }^{-1}$ at $800 \mathrm{~m}$ to reach values in the 2340-2360 range at $1200 \mathrm{~m}$, with the highest values relating to the highest salinities and maximum Mediterranean contribution. The $A_{\mathrm{T}}$ slightly decreases down to $2000 \mathrm{~m}$ $\left(2339 \pm 1 \mu \mathrm{mol} \mathrm{kg}^{-1}\right)$ to increase thereafter to the bottom, with values of around $2356 \pm 2 \mu \mathrm{mol} \mathrm{kg}{ }^{-1}$. After normalization, the $N A_{\mathrm{T}}$ continues increasing from $2316 \pm 2 \mu \mathrm{mol} \mathrm{kg}-1$ at $1000 \mathrm{~m}$ to $2361 \pm 1 \mu \mathrm{mol} \mathrm{kg}-1$ at $3670 \mathrm{~m}$.

\subsection{Trends in surface partial pressure of $\mathrm{CO}_{2}$}

The vertical distributions of the carbonate system variables determined over the 10 years at the ESTOC can also provide trends that indicate changes in the chemical, biological and physical characteristics of the seawater in the area over time. Santana-Casiano et al. (2007) provided surface water $(10 \mathrm{~m})$ trends and the seasonal variability for the various different 
Table 1. The time series of properties at ESTOC over 12 selected depths and for the mixed layer (ML) for the decade 1995 to 2004 . Linear regression coefficients and standard deviation at ESTOC provided the rate of change (expressed as $\Delta X_{i}$ in $\mu \mathrm{mol} \mathrm{kg}^{-1} \mathrm{yr}^{-1}$ ) for the carbonate system variables.

\begin{tabular}{ccccccccc}
\hline Levels & $\Delta N C_{\mathrm{T}}$ & $\Delta C_{\mathrm{T}}$ & $\Delta \mathrm{pH}_{25} \times 10^{3}$ & $\Delta \mathrm{pH}_{\mathrm{is}} \times 10^{3}$ & $\Delta\left[\mathrm{HCO}_{3}^{-}\right]$ & $\Delta\left[\mathrm{CO}_{3}^{2-}\right]$ & $\Delta \Omega_{\text {cal }} \times 10^{2}$ & $\Delta \Omega_{\text {arg }} \times 10^{2}$ \\
\hline 10 & $0.87 \pm 0.24$ & $0.94 \pm 0.50$ & $-1.8 \pm 0.3$ & $-1.4 \pm 0.7$ & $1.18 \pm 0.21$ & $-0.90 \pm 0.08$ & $-2.09 \pm 0.23$ & $-1.40 \pm 0.18$ \\
50 & $0.88 \pm 0.22$ & $0.86 \pm 0.42$ & $-1.8 \pm 0.4$ & $-1.5 \pm 0.8$ & $1.30 \pm 0.20$ & $-0.86 \pm 0.09$ & $-2.05 \pm 0.22$ & $-1.35 \pm 0.16$ \\
100 & $0.82 \pm 0.16$ & $0.80 \pm 0.49$ & $-1.6 \pm 0.3$ & $-1.4 \pm 0.5$ & $1.30 \pm 0.16$ & $-0.82 \pm 0.06$ & $-1.88 \pm 0.15$ & $-1.24 \pm 0.10$ \\
$\mathrm{ML}$ & $0.85 \pm 0.16$ & $0.87 \pm 0.48$ & $-1.7 \pm 0.3$ & $-1.4 \pm 0.6$ & $1.24 \pm 0.18$ & $-0.85 \pm 0.07$ & $-1.98 \pm 0.19$ & $-1.32 \pm 0.14$ \\
200 & $0.77 \pm 0.25$ & $0.81 \pm 0.40$ & $-1.3 \pm 0.5$ & $-1.0 \pm 0.4$ & $0.94 \pm 0.27$ & $-0.68 \pm 0.09$ & $-1.22 \pm 0.21$ & $-0.81 \pm 0.14$ \\
300 & $0.53 \pm 0.23$ & $0.57 \pm 0.34$ & $-1.0 \pm 0.4$ & $-1.1 \pm 0.5$ & $0.40 \pm 0.17$ & $-0.34 \pm 0.08$ & $-0.71 \pm 0.20$ & $-0.48 \pm 0.13$ \\
600 & $0.49 \pm 0.13$ & $0.39 \pm 0.27$ & $-0.8 \pm 0.3$ & $-0.6 \pm 0.3$ & $0.34 \pm 0.08$ & $-0.26 \pm 0.03$ & $-0.34 \pm 0.06$ & $-0.21 \pm 0.04$ \\
1000 & $0.40 \pm 0.14$ & $0.29 \pm 0.15$ & $-0.8 \pm 0.3$ & $-0.5 \pm 0.3$ & $0.49 \pm 0.09$ & $-0.20 \pm 0.03$ & $-0.24 \pm 0.10$ & $-0.24 \pm 0.04$ \\
1500 & $0.27 \pm 0.08$ & $0.14 \pm 0.08$ & $-0.5 \pm 0.1$ & $-0.2 \pm 0.1$ & $0.06 \pm 0.08$ & $-0.06 \pm 0.02$ & $-0.09 \pm 0.04$ & $-0.08 \pm 0.04$ \\
2000 & $0.03 \pm 0.09$ & $0.02 \pm 0.08$ & $-0.5 \pm 0.2$ & $-0.4 \pm 0.1$ & $0.12 \pm 0.06$ & $-0.15 \pm 0.04$ & $-0.06 \pm 0.04$ & $-0.03 \pm 0.02$ \\
2500 & $0.22 \pm 0.08$ & $0.14 \pm 0.10$ & $-0.6 \pm 0.2$ & $-0.7 \pm 0.1$ & $0.44 \pm 0.10$ & $-0.20 \pm 0.04$ & $-0.10 \pm 0.04$ & $-0.04 \pm 0.02$ \\
3000 & $0.11 \pm 0.06$ & $0.09 \pm 0.10$ & $-0.4 \pm 0.1$ & $-0.3 \pm 0.1$ & $0.10 \pm 0.06$ & $-0.09 \pm 0.01$ & $-0.03 \pm 0.02$ & $-0.02 \pm 0.01$ \\
3500 & $0.00 \pm 0.07$ & $0.03 \pm 0.06$ & $-0.2 \pm 0.2$ & $-0.1 \pm 0.2$ & $0.01 \pm 0.04$ & $-0.01 \pm 0.02$ & $-0.01 \pm 0.02$ & $-0.01 \pm 0.02$ \\
\hline
\end{tabular}

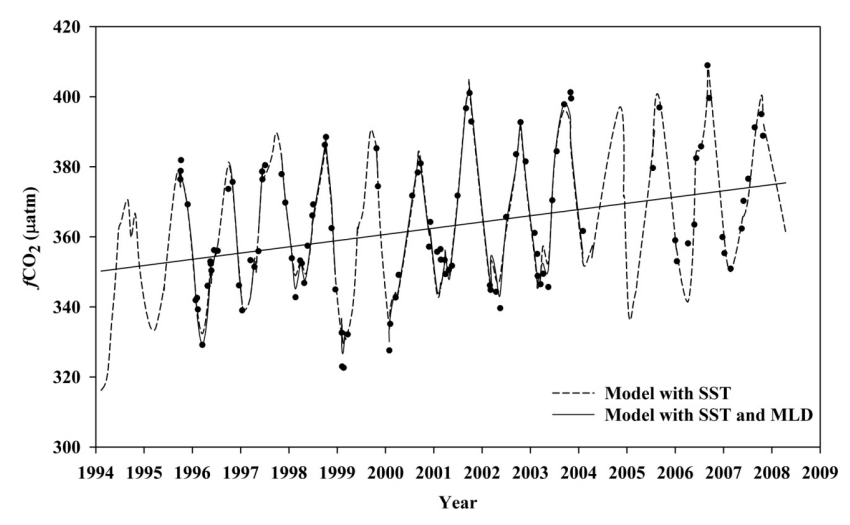

Fig. 3. Long-term trends of surface $(10 \mathrm{~m})$ oceanic partial pressure of $\mathrm{CO}_{2}$ expressed as fugacity, $f \mathrm{CO}_{2}$, observed at the ESTOC site (European Station for Time series at the Ocean, the Canary Islands) $\left(29^{\circ} 10^{\prime} \mathrm{N}, 15^{\circ} 30^{\prime} \mathrm{W}\right)$ located north of the Canary Islands in the North East Atlantic Ocean. The model fit corresponds to Eq. (4) (continuous line) for data from September 1995 to February 2004 considering the sea surface temperature (SST) and the mixed layer depth (Santana-Casiano et al., 2007) and to Eq. (5) (dotted line) that uses SST from 1995 to 2008 and applied to the full data set of ESTOC. The slope of the regression line is $1.75 \pm 0.37 \mu \mathrm{atm} \mathrm{yr}^{-1}$.

carbonate system variables. The partial pressure of the $\mathrm{CO}_{2}$, expressed as fugacity of $\mathrm{CO}_{2}, f \mathrm{CO}_{2}$, increased at a rate of $1.55 \pm 0.43 \mu \mathrm{atm} \mathrm{yr}^{-1}$ for the period from 1995 to 2004 , after removing seasonality. This annual rate was similar to that of $1.6 \pm 0.7 \mu \mathrm{atm} \mathrm{yr}^{-1}$ for the atmospheric increase in $\mathrm{CO}_{2}$ at the atmospheric station Izaña for the same period of time, confirming an ocean equilibration process with increasing $\mathrm{CO}_{2}$ in the atmosphere. The $f \mathrm{CO}_{2}$ values at ESTOC were found to be strongly related to seasonal temperature variability (González-Dávila et al., 2003; Santana-Casiano et al., 2007). Figure 3 presents an updated image for the experimental surface $f \mathrm{CO}_{2}$ values at the ESTOC through to 2008 , together with model fitting equations for the experimental data

$$
\begin{aligned}
f \mathrm{CO}_{2}= & -3336.9+1.723 \cdot t+12.22 \cdot T-0.018 \cdot \mathrm{MLD} \\
& +6.81 \cdot \sin (2 \pi \cdot t)
\end{aligned}
$$

where $t$ is time in years, $T\left({ }^{\circ} \mathrm{C}\right)$ is the temperature at $10 \mathrm{~m}$ and MLD as of Santana-Casiano et al. (2007) refers to the mixed layer depth at ESTOC $\left(R^{2}=0.94\right.$, standard error of estimate $=4.9 \mu \mathrm{atm})$. The MLD is included to account for the influence of vertical advection on the winter convective mixing. The function indicates an average annual increase of $1.72 \pm 0.22 \mu \mathrm{atm} \mathrm{yr}^{-1}$ when the $T$ and MLD are kept constant. If the MLD is not taken into consideration, as was the case in Santana-Casiano et al. (2007), then

$\left.f \mathrm{CO}_{2}=-2977.5+1.62 \cdot t+12.16 \cdot T+7.15 \cdot \sin (2 \pi \cdot t)\right)$

where $R^{2}=0.93$ and a standard error of estimate of $5.3 \mu \mathrm{atm}$ has been calculated. This function shows an average annual increase of $1.66 \pm 0.12 \mu \mathrm{atm} \mathrm{yr}^{-1}$, slightly higher than the value obtained considering only data through to 2004 . Using Eq. (5) and data for temperature from the initial ESTOC data-base, the values for $f \mathrm{CO}_{2}$ were estimated as of January 1994 (Fig. 3). The linear regression for the estimated data was $1.75 \pm 0.37 \mu \mathrm{atm} \mathrm{yr}^{-1}$. The increased trend observed when data for the years 2005 to 2008 were included confirms the strong correlation observed for $f \mathrm{CO}_{2}$ trends between the atmosphere (present trends close to $2 \mu \mathrm{atm} \mathrm{yr}^{-1}$ ) and the ocean for the Subtropical Gyre waters, as was observed at BATS (Bates, 2007) and indicated previously at the ESTOC (Santana-Casiano et al., 2007). 


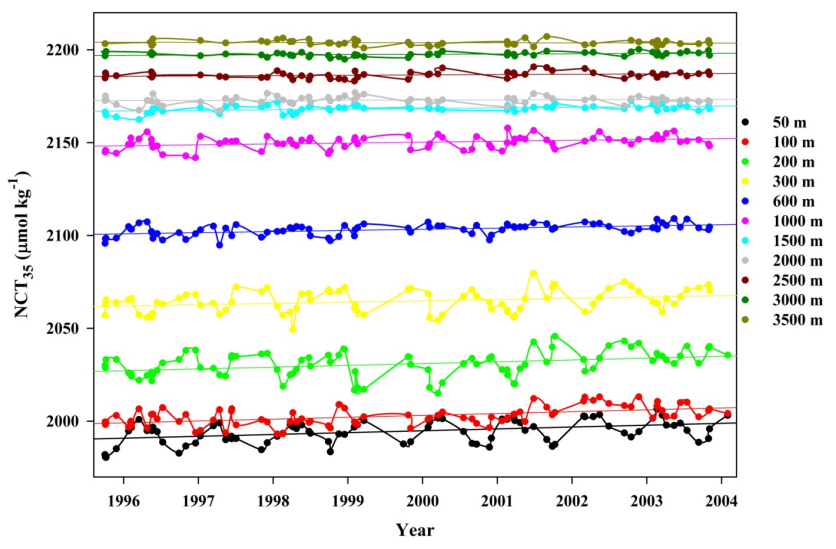

Fig. 4. Long-term trends of the water column $C_{\mathrm{T}}$ normalized to a constant salinity of $35, N C_{\mathrm{T}}\left(\mu \mathrm{mol} \mathrm{kg}{ }^{-1}\right)$ for the mixed layer and for selected depths at ESTOC. The slope and standard deviation of the linear regressions are presented in Table 1.

\subsection{Trends in water column carbonate variables}

A similar study was carried out for data over the water column at ESTOC by considering the values determined at selected depths between 1995 and 2004. A total of 12 depth values were used to define the inter-annual variability for the carbon dioxide parameters at ESTOC, 7 of which were located over the first $1000 \mathrm{~m}$. While sampling strategies at ESTOC attempt to maintain fixed sampling positions, on the same cruises, sampling depths varied over $10 \mathrm{~m}$ from the selected ones. In these cases, linear interpolation between the values for the two closest sampling depths was carried out as presented in Figs. 4 and 5 for the $N C_{\mathrm{T}}$ and $\mathrm{pH}_{\mathrm{T}, 25}$, respectively. Table 1 presents the corresponding linear regression coefficients and standard deviation for the carbon dioxide variables at ESTOC. Due to the constancy of these trends in the mixed layer at ESTOC, the average values were also included.

The $C_{\mathrm{T}}$ at the mixed layer (Fig. 4, regional normalized to salinity of 35) follows the seasonal solar cycle at the ESTOC, primarily driven by seasonal changes in surface heat and wind stress. During Winter, the surface cooling and wintertime convective mix decrease the surface temperature to values around $18-19^{\circ} \mathrm{C}$ (Fig. 2) with MLD over $100 \mathrm{~m}$, bringing more cold, $C_{\mathrm{T}}$-rich sub-surface waters up from the deep. A thermal stratification is present from April to October, largely due to heat fluxes, but with reduced effects due to the Trade Winds, which are prevalent from May to the end of September (Santana-Casiano et al., 2007), when the MLD is reduced to the first $25 \mathrm{~m}$. The drawdown of $C_{\mathrm{T}}$ in the Spring-Summer manifests the biological uptake in the mixed-layer. The amplitudes and the effects are related to the inter-annual variability of the mixed layer depth that fluctuates between $120 \mathrm{~m}(1998,2003)$ and $200 \mathrm{~m}(1996,1999$, 2000) (González-Dávila et al., 2007). An important inter-

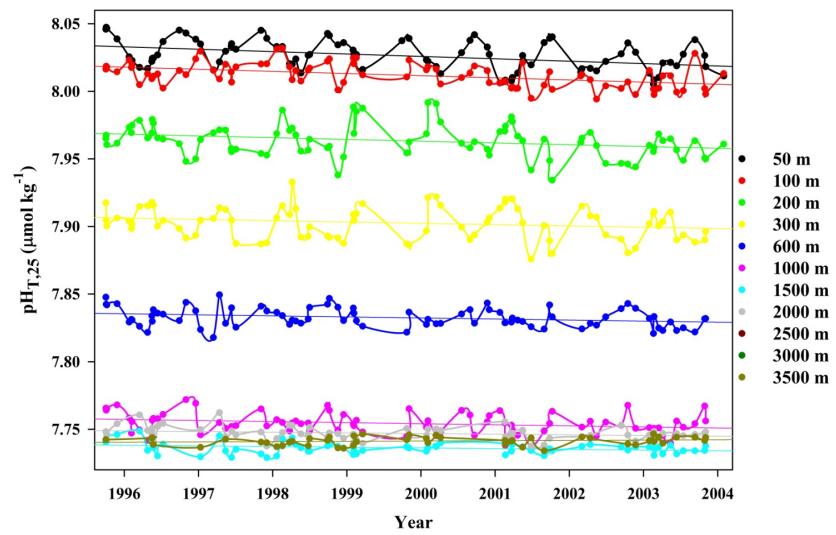

Fig. 5. Long-term trends of the observed water column $\mathrm{pH}$ in a total scale at $25^{\circ} \mathrm{C}, \mathrm{pH}_{\mathrm{T}, 25}$ for selected depths at ESTOC and for seawater in the mixed layer. The slope and standard deviation of the linear regressions are presented in Table 1.

annual increase in $N C_{\mathrm{T}}$ is also to be clearly observed over the years with values of $0.85 \pm 0.16 \mu \mathrm{mol} \mathrm{kg}^{-1} \mathrm{yr}^{-1}$ (Table 1) in the MLD. An increase of $C_{\mathrm{T}}$ of $0.87 \pm 0.48 \mu \mathrm{mol} \mathrm{kg} \mathrm{gr}^{-1}$ was also determined, which indicates non-significant effects of salinity changes on the observed annual increase in surface $C_{\mathrm{T}}$ (Fig. 2). The slope is equivalent to an $f \mathrm{CO}_{2}$ increase of $1.5 \pm 0.6 \mu \mathrm{atm} \mathrm{yr}^{-1}$ by applying Lewis and Wallace (1998). The robustness of the inter-annual inorganic carbon signal was investigated by considering the integrated $N C_{\mathrm{T}}$ throughout Winter (December to March) in the mixed layer values over the years, since Winter is the time of the year when the mixed layer is deepest and coldest (Cianca et al., 2007). The slope of the regression line indicates an increase in the mixed layer $N C_{\mathrm{T}}$ content of $0.90 \pm 0.6 \mu \mathrm{mol} \mathrm{kg}^{-1} \mathrm{yr}^{-1}$, equivalent to an annual $f \mathrm{CO}_{2}$ increase of $1.5 \pm 0.9 \mu \mathrm{atm} \mathrm{yr}^{-1}$, similar to the value observed in the atmospheric $\mathrm{CO}_{2}$ increase for the period 1995 to 2004. At intermediate depths of 300, 600, and $1000 \mathrm{~m}$, we observed an annual increase in the $N C_{\mathrm{T}}$ of $0.53,0.49$ and $0.40 \mu \mathrm{mol} \mathrm{kg}^{-1} \mathrm{yr}^{-1}$, respectively (Fig. 4, Table 1). At $1500 \mathrm{~m}$, an increase of $0.27 \mu \mathrm{mol} \mathrm{kg}^{-1} \mathrm{yr}^{-1}$ over the whole decade can be considered within the limits of accuracy for inorganic carbon computation, using $\mathrm{pH}$ and $A_{\mathrm{T}}$. Down at $2000 \mathrm{~m}$, the values are always under the estimated margin of error and any conclusions should be drawn with care. However, what is observed not only for the $N C_{\mathrm{T}}$ but also for the other parameters in Table 1, is a relative maximum at the depth range of 2500-3000 m that may be connected to the influence of NADW as it spreads southward through the North Atlantic Ocean. The formation of the North Atlantic Deep Water is a unique process, transporting anthropogenic $\mathrm{CO}_{2}$ into the ocean's interior, making the deep waters rich in anthropogenic carbon in the Northern North Atlantic that can influence the waters at 2500-3000 m depth in the region of the Canary Islands. 

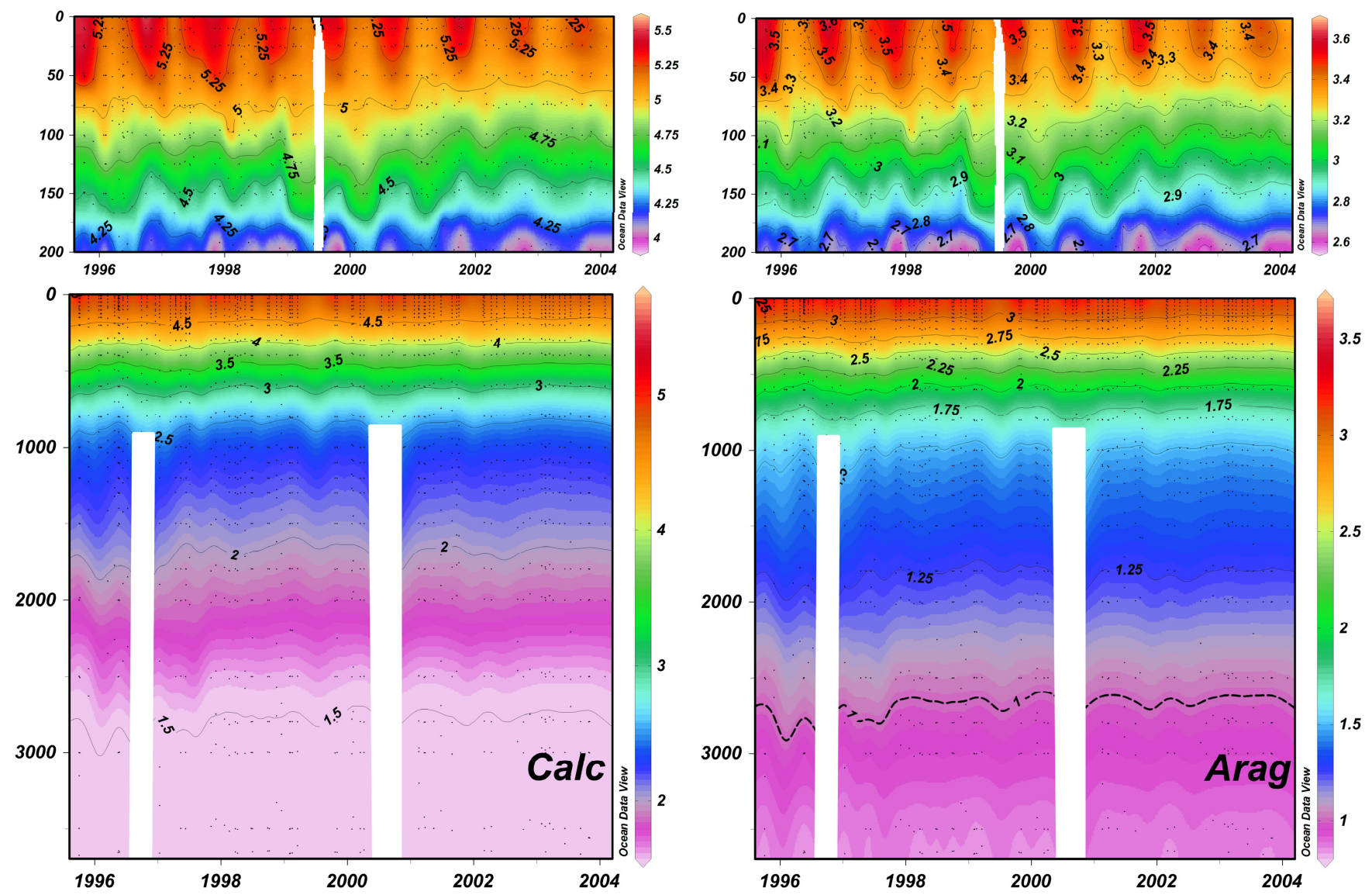

Fig. 6. Hovmöller diagram of the water column calcite saturation state, $\Omega_{\text {calc }}$, and aragonite saturation state, $\Omega_{\text {Arag }}$.

The $N A_{\mathrm{T}}$ remains constant over the years (data not shown) at the different water depths, as is to be observed for the surface waters, with standard deviations close to the analytical error of alkalinity measurements. This suggests that the potential contribution of the formation and/or dissolution of $\mathrm{CaCO}_{3}$ and the consumption and/or re-mineralization of nitrate remain constant with the observed $N A_{\mathrm{T}}$ variability at ESTOC. Bates (2001) and Winn et al. (1998) also reported that the change in time of the $A_{\mathrm{T}}$ in the mixed layer is insignificant at the sub-tropical stations of BATS and HOT.

The addition of $\mathrm{CO}_{2}$ acidifies seawater and lowers its $\mathrm{pH}$. The experimental data with respect to the $\mathrm{pH}_{\mathrm{T}, 25}$ at the ESTOC site clearly confirm the decrease in $\mathrm{pH}$ over the first $1000 \mathrm{~m}$ (Fig. 5 and Table 1). The values in the MLD for the $\mathrm{pH}_{\mathrm{T}, 25}$ decrease at a rate of around 0.0017, similar to that computed in the west Subtropical North Atlantic, at the BATS site (Bates, 2007). The values are statistically significant at $95 \%$ confidence level down over the first $1000 \mathrm{~m}$, where the $\mathrm{pH}_{\mathrm{T}, 25}$ decreases at a rate of $0.0008 \pm 0.0003$ units $\mathrm{yr}^{-1}$. Values at $25^{\circ} \mathrm{C}$ are slightly higher than those at in situ conditions that ponder the effect of temperature on the carbonate equilibria, related to both the small and almost symmetrical seasonal temperature cycle in ESTOC (Santana-
Casiano et al., 2007). The observed rate of the $\mathrm{pH}$ decline in the mixed layer compared well with the rate predicted, based on the equilibration of atmospheric $\mathrm{CO}_{2}$ with the surface seawater $\left(-0.0017 \pm 0.00003 \mathrm{yr}^{-1}\right)$. As indicated above for $C_{\mathrm{T}}$, the $\mathrm{pH}$ decreases to a slightly greater extent at the 2500 core than in surrounding waters at $2000 \mathrm{~m}$ and at the bottom.

The observed values of the $A_{\mathrm{T}}$ and $\mathrm{pH}_{\mathrm{T}, 25}$ were also considered when computing the concentration of the corresponding carbonic acid species at the ESTOC site (Table 1). The increase in the total inorganic carbon and the reduction in the $\mathrm{pH}$ affect the carbonate species distribution with an increase in the bicarbonate concentration at a rate of $1.2-1.3 \mu \mathrm{mol} \mathrm{kg}^{-1} \mathrm{yr}^{-1}$ in the MLD, whereas the carbonate ion concentration decreases at a rate of 0.82 $0.90 \mu \mathrm{mol} \mathrm{kg} \mathrm{gr}^{-1}$. These effects can also be followed down through the first $1000 \mathrm{~m}$ where the bicarbonate concentration in 2004 was around $5 \mu \mathrm{mol} \mathrm{kg}^{-1}$ higher than during $1996\left(2038.8 \mu \mathrm{mol} \mathrm{kg}^{-1}\right)$. Conversely, and for the same period, the carbonate concentration decreased by 2 units from a value in 1996 of $199 \mu \mathrm{mol} \mathrm{kg}{ }^{-1}$. The decrease in $\mathrm{pH}$ and carbonate concentration also affects the states of saturation of both calcite, $\Omega_{\mathrm{cal}}$, and aragonite, $\Omega_{\mathrm{arag}}$ (Fig. 6). Both of them decrease rapidly with depth over the upper $1000 \mathrm{~m}$ 


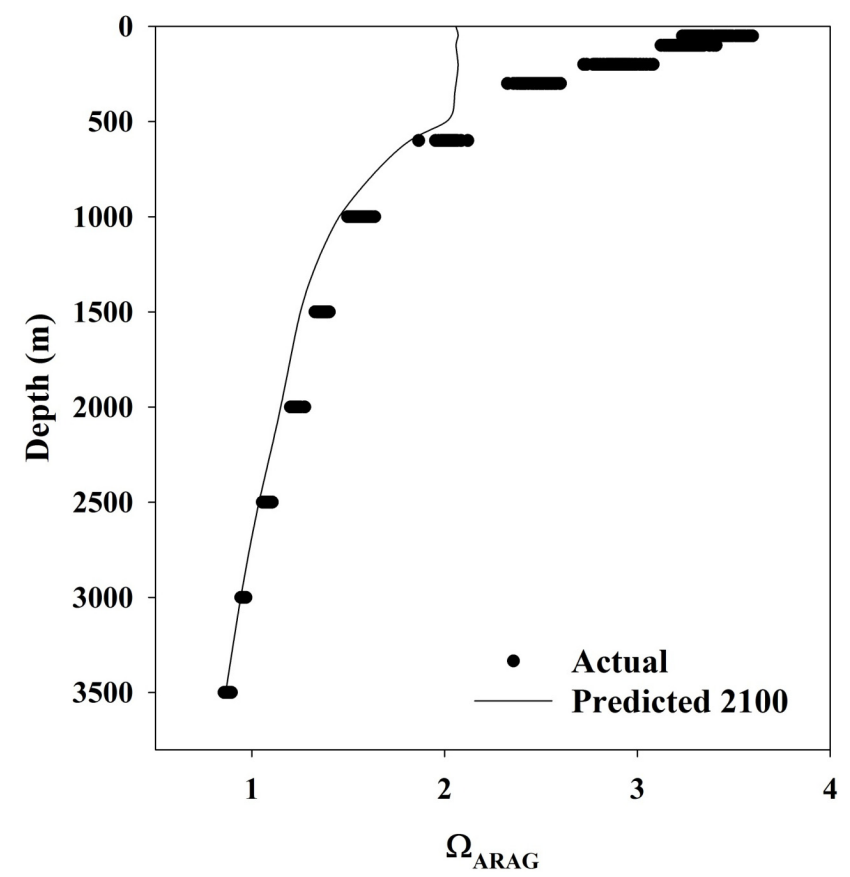

Fig. 7. The average vertical profile of the aragonite saturation state, $\Omega_{\text {Arag }}$ for data in the period between 1995-2004 and predicted values for the year 2100 in line with the trends presented in Table 1 for the ten years between 1995-2004.

due to the decrease in carbonate concentration and changes in pressure and temperature and in $f \mathrm{CO}_{2}$. $\Omega_{\text {cal }}$ decreases from a value over 5 at $100 \mathrm{~m}$ to around 2 at $1000 \mathrm{~m}$ while $\Omega_{\text {arag }}$ decreases from a value of $3.4 \pm 0.2$ in surface waters to $1.4 \pm 0.1$ at $1000 \mathrm{~m}$, and $1 \pm 0.1$ at $2800 \mathrm{~m}$. Below $1000 \mathrm{~m}$, both decrease at a slower rate, due to the controlled effect of temperature and pressure on the increase in the solubility product. Over the ten years from 1995 to 2004 , the $\Omega_{\text {cal }}$ over the first $100 \mathrm{~m}$ at the ESTOC decreased 0.2 units from an initial value in 1995 of $5.44 \pm 0.14$, whereas the $\Omega_{\text {arag }}$ moved from $3.55 \pm 0.09$ in 1995 to $3.4 \pm 0.08$ in 2004 (Fig. 6, Table 1). If the $\Omega_{\text {arag }}$ rate of change for the decade 1995-2004 will continue for this century, a value of around $2.1 \pm 0.1$ will be found in the surface waters of the ESTOC by 2100. According to the rate of decrease calculated at the different depths presented in Table 1 , the $\Omega_{\text {arag }}$ profile will change its exponential decay with depth to form a homogenous layer of about $600 \mathrm{~m}$ with $\Omega_{\text {arag }}$ of $2 \pm 0.2$ and with values of $1.2 \pm 0.1$ at $1500 \mathrm{~m}$ (Fig. 7).

\subsection{Factors controlling the depth distribution of $A_{\mathrm{T}}$ and $\boldsymbol{C}_{\mathrm{T}}$}

Figure 8 depicts the distributions of $A_{\mathrm{T}}$ and $C_{\mathrm{T}}$ vs. salinity at the ESTOC site together with a typical potential temperature vs. salinity plot. The lines in Fig. 8 represent the hypothetical mixing lines between the water masses and can be

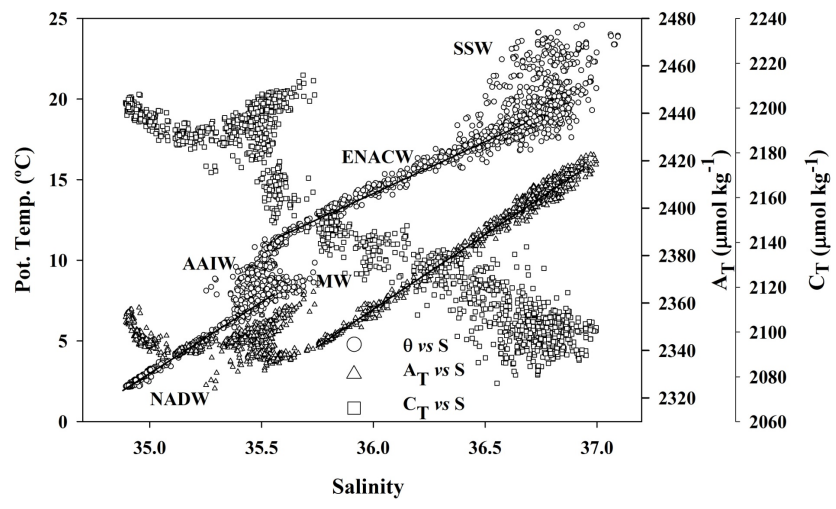

Fig. 8. Potential temperature vs. salinity relationship at the ESTOC site (open circles). SSW, ENACW, AAIW, MW and NADW indicate surface sea water, East North Atlantic central water, Antarctic Intermediate water, Mediterranean water and North Atlantic deep water. Lines represent the hypothetical linear mixing lines between two water types. $A_{\mathrm{T}}$ (open triangles) and $C_{\mathrm{T}}$ (open squares) vs. salinity relationships are also included.

inferred to be the result of mixes of the different water types in the region (Pérez et al., 2001). A linear mixing line between $A_{\mathrm{T}}$ and salinity fits well within the ENACW region, evidencing that the physical mixing rates are faster than the $A_{\mathrm{T}}$ changes caused by biological processes. On the contrary, the non-linear mixing behavior observed in the $C_{\mathrm{T}}$ vs. the salinity plot suggests that the biological production of carbonate and organic carbon controls the depth distributions of $C_{\mathrm{T}}$ in the ENACW. In the intermediate water, a mix of at least three different water types (including MW, AAIW and ENACWp in the upper part,and NADW in the lower mixing triangle) should be considered, and linearity is not even to be observed in the potential temperature vs. salinity plot (see Pérez et al., 2001). In deeper waters, both the $A_{\mathrm{T}}$ and $C_{\mathrm{T}}$ are outside the theoretical values to be expected from purely linear mixing lines (Fig. 8). This non-linearity indicates that the carbonate dissolution and organic matter decomposition are the processes responsible for the vertical distributions of $A_{\mathrm{T}}$ and $C_{\mathrm{T}}$ observed in deep waters.

In order to examine the general processes controlling the vertical variations of alkalinity and the inorganic carbon distribution, we applied the initial Chen and Millero (1979) model for the decomposition of the water column $A_{\mathrm{T}}$ and $C_{\mathrm{T}}$ contributors. Three major components may be taken into consideration: (1) the values of the water mass at the time of its formation at surface outcrops, the pre-formed values; (2) changes due to the organic carbon pump, related to organic matter decomposition; (3) changes due to the carbonate pump caused by carbonate dissolution (Chou et al., 2007). After using the regional salinity normalization procedure indicated in the experimental section:

$$
N A_{\mathrm{T}}^{\text {meas }}=N\left(A_{\mathrm{T}}^{\text {pre }}+A_{\mathrm{T}}^{\text {org }}+A_{\mathrm{T}}^{\text {carb }}\right)
$$




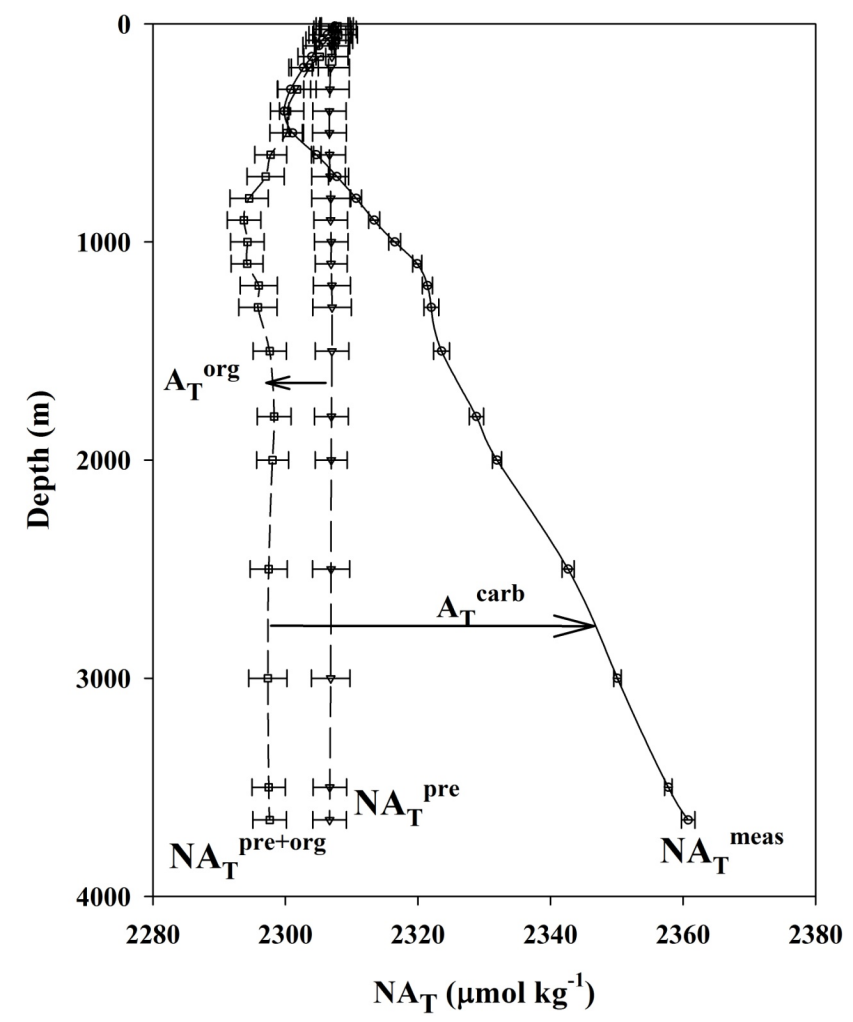

Fig. 9. Depth profiles of measured $N A_{\mathrm{T}}\left(N A_{\mathrm{T}}^{\text {meas }}\right.$, open circles), pre-formed $N A_{\mathrm{T}}\left(N A_{\mathrm{T}}^{\text {pre }}\right.$, open triangles), and preformed plus organic change contribution to the $N A_{\mathrm{T}}\left(N A_{\mathrm{T}}^{\mathrm{pre}+\mathrm{org}}\right.$, open squares) at the ESTOC site for the period between 1995 and 2004. The definitions and calculations for each component are given in the text. Horizontal bars represent the variation of $N A_{\mathrm{T}}^{\text {meas }}$ at a given depth over the 87 cruises and the uncertainties in the $N A_{\mathrm{T}}^{\mathrm{pre}}$ and $N A_{\mathrm{T}}^{\mathrm{pre}+\mathrm{org}}$ calculations.

$N C_{\mathrm{T}}^{\text {meas }}=N\left(C_{\mathrm{T}}^{\text {pre }}+C_{\mathrm{T}}^{\text {org }}+C_{\mathrm{T}}^{\text {carb }}\right)$

where the super-scripts "meas", "pre", "org" and "carb" indicate, respectively, measured, pre-formed, organic decomposition and carbonate dissolution.

The pre-formed alkalinity values were computed using the function proposed by Wanninkhof et al. (1999) which deploys $A_{\mathrm{T}}$, salinity and $\mathrm{NO}\left(\mathrm{NO}=10.6 \mathrm{NO}_{3}+\mathrm{O}_{2}\right)$ data from the top $100 \mathrm{~m}$ data set obtained at around $25 / 32^{\circ} \mathrm{W}$ from $43^{\circ} \mathrm{S}$ to $62^{\circ} \mathrm{N}$, occupied as part of the NOAA-OACES in July 1991 and July/August 1993, and reported with a margin of uncertainty of $5.2 \mu \mathrm{mol} \mathrm{kg} \mathrm{kg}^{-1}$.

$A_{\mathrm{T}}^{\mathrm{pre}}=278.4+57.91 \cdot S+0.0074 \cdot \mathrm{NO}$

Pérez et al. (2002) compared various parameterizations and indicated that the above may be considered to be a correct model of the $A_{\mathrm{T}}^{\mathrm{pre}}$ of water masses in the North Atlantic. Normalized preformed values, $N A_{\mathrm{T}}^{\mathrm{pre}}$, combining Eqs. (8) and (1), were kept constant to $2307 \pm 0.18 \mu \mathrm{mol} \mathrm{kg}^{-1}$.

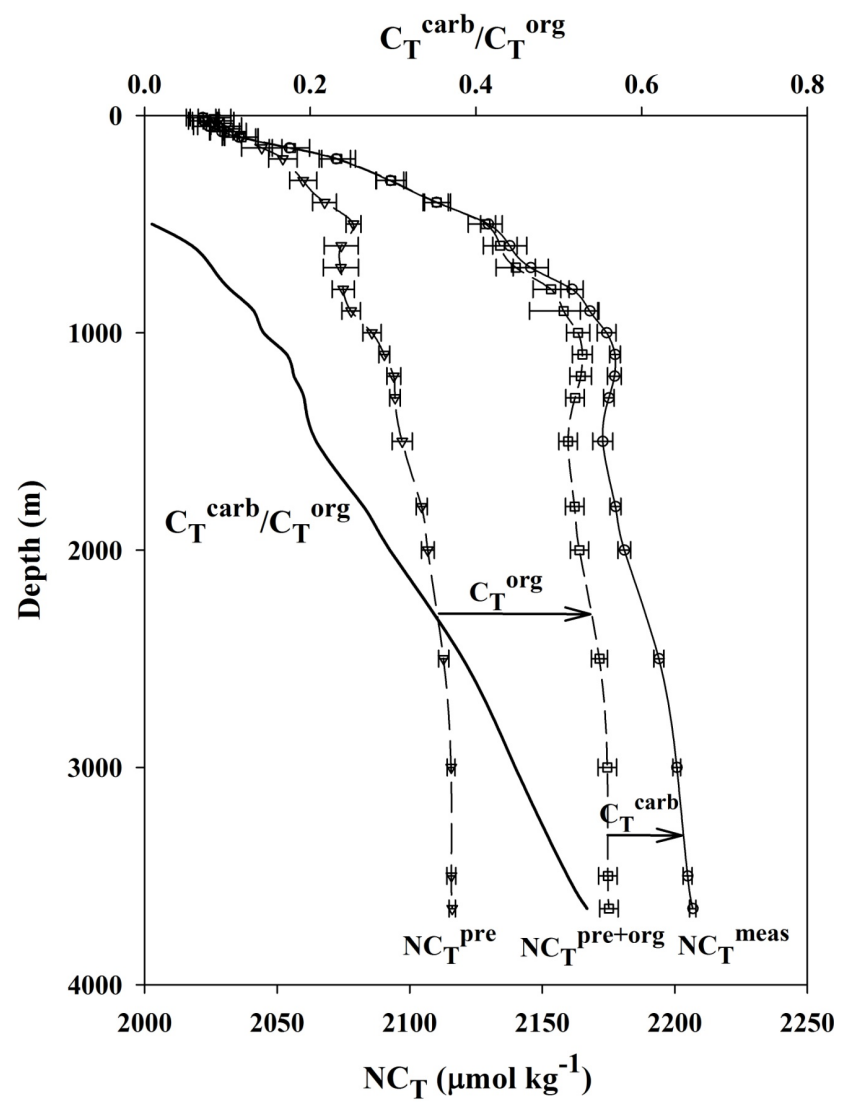

Fig. 10. Depth profiles of measured $N C_{\mathrm{T}}\left(N C_{\mathrm{T}}^{\text {meas }}\right.$, open circles), pre-formed $N C_{\mathrm{T}}\left(N C_{\mathrm{T}}^{\text {pre }}\right.$, open triangles), and pre-formed plus organic change contribution to the $N C_{\mathrm{T}}\left(N C_{\mathrm{T}}^{\text {pre+org }}\right.$, open squares $)$ at the ESTOC site for the period between 1995 and 2004. The definitions and calculations of each component are given in the text. The horizontal bars represent the variation of $N C_{\mathrm{T}}^{\text {meas }}$ at a given depth over the 87 cruises and the uncertainties in the $N C_{\mathrm{T}}^{\text {pre }}$ and $N C_{\mathrm{T}}^{\text {pre+org }}$ calculations. The ratio between the contributions due to the dissolution of particulate carbonates and organic matter remineralization, together with the $C_{\mathrm{T}}^{\text {carb }} / C_{\mathrm{T}}^{\text {org }}$, at ESTOC implying their relative contribution to the increase of $C_{\mathrm{T}}$ in the water column are also included.

The effects on total alkalinity changes as related to the organic matter production and remineralization are estimated using apparent oxygen utilization (AOU) and the links with the change in nitrate concentration $\left(R_{\mathrm{N}}=\Delta \mathrm{N} / \Delta \mathrm{O}_{2}=\right.$ $16 / 170$, stoichiometric coefficient as taken from Anderson and Sarmiento, 1994) proportional to the proton flux during photosynthesis and decomposition (Chen and Millero, 1979).

$A_{\mathrm{T}}^{\mathrm{org}}=-\mathrm{AOU} \cdot R_{\mathrm{N}}$

Figure 9 presents the corresponding effects of organic matter formation and decomposition plotted as $N\left(A_{\mathrm{T}}^{\mathrm{pre}}+A_{\mathrm{T}}^{\mathrm{org}}\right)$, with the difference between the values of this line and the preformed values a measure of the organic contribution. Each individual ESTOC data series was treated, normalized and 
then averaged for each depth and plotted together with the standard deviation and the uncertainties in the calculation.

Following Eq. (6) the contribution made by the dissolution of particulate carbonates can be determined as the difference between the $N A_{\mathrm{T}}^{\text {meas }}$ and $N\left(A_{\mathrm{T}}^{\mathrm{pre}}+A_{\mathrm{T}}^{\mathrm{org}}\right)$. The hard material decomposition contribution $A_{\mathrm{T}}^{\text {carb }}$ varies with depth. It appears after $400 \mathrm{~m}$ and increases sharply at $1200 \mathrm{~m}$ where it remains constant down to $1500 \mathrm{~m}$, then increasing again through to the bottom. This shows that a considerable portion of the surface produced calcite and aragonite dissolves in the upper $1000 \mathrm{~m}$, contributing with $23 \mu \mathrm{mol} \mathrm{kg}^{-1}$ to the alkalinity above the lysocline, probably as a result of biological mediation (Milliman et al., 1999). The dissolution of hard material predominates in deeper water as the result of increased pressure, decreased temperature and longer residence time, controlling the vertical profiles of $N A_{\mathrm{T}}^{\text {meas }}$. Over the first $400 \mathrm{~m}$, the values in $N A_{\mathrm{T}}^{\mathrm{pre}}$ determine the distribution of alkalinity while the $A_{\mathrm{T}}^{\text {org }}$ balances the vertical gradient of $N A_{\mathrm{T}}^{\text {meas }}$. In the first $1000 \mathrm{~m}$, remineralization of organic material lowers alkalinity by an amount about equal to the amount of nitrate released. However, the alkalinity decrease is about $13 \mu \mathrm{mol} \mathrm{kg}{ }^{-1}$ whereas nitrate increases by $20 \mu \mathrm{mol} \mathrm{kg}^{-1}$ (data not shown). This discrepancy again can be interpreted as evidence for shallow-depth calcium carbonate dissolution (SDCCD). As it is indicated by Friis et al. (2007), the normalization procedure (Eq. 1) allows that such small effects can be picked up from the observed distribution. The remineralization phenomenon is not masked or compensated by a strong SDCCD.

In order to correct the total inorganic carbon for biological activity, both the soft-tissue and the carbonate pumps should be taken into consideration (Eq. 4). The contribution due to organic matter remineralization is computed from the $\mathrm{AOU}$ and the stoichiometric coefficient $R_{\mathrm{C}}=\Delta \mathrm{C} / \Delta \mathrm{O}_{2}=117 / 170$ (Anderson and Sarmiento, 1994)

$C_{\mathrm{T}}^{\text {org }}=R_{\mathrm{C}} \cdot \mathrm{AOU}$

Following Chen and Millero (1979), the dissolution of hardtissue results in an increase in molar ratio $2 / 1$ for the $A_{\mathrm{T}}$ and $C_{\mathrm{T}}$, and, therefore, the $C_{\mathrm{T}}^{\mathrm{carb}}$ is half of the contribution estimated for $A_{\mathrm{T}}^{\text {carb }}$. Following Eq. (7), the $N C_{\mathrm{T}}^{\text {pre }}$ can be computed as $N\left(C_{\mathrm{T}}^{\text {meas }}-\left(C_{\mathrm{T}}^{\text {org }}+C_{\mathrm{T}}^{\text {carb }}\right)\right)$. The results are plotted on Fig. 10. In the first $500 \mathrm{~m}, N C_{\mathrm{T}}^{\text {meas }}$ increases in $108 \pm 4 \mu \mathrm{mol} \mathrm{kg}^{-1}, 49 \%$ related to the increase in the preformed values and $51 \%$ due to the re-mineralization of organic matter. From $500 \mathrm{~m}$ to the bottom, the $N C_{\mathrm{T}}^{\text {meas }}$ continues to increase by around $75 \mu \mathrm{mol} \mathrm{kg}-1$, to $40 \pm 3 \mu \mathrm{mol} \mathrm{kg}-1$ accounted for by the pre-formed $N C_{\mathrm{T}}$ and $31 \pm 3 \mu \mathrm{mol} \mathrm{kg}-1$ due to the carbonate dissolution. The amount contributed by the dissolution of soft tissues is low at $500 \mathrm{~m}$. The $C_{\mathrm{T}}^{\text {org }}$ contribution is maximum at around $900-1000 \mathrm{~m}, 80 \pm$ $7 \mu \mathrm{mol} \mathrm{kg}{ }^{-1}$, decreasing to $70 \pm 4 \mu \mathrm{mol} \mathrm{kg}-1$ at $1500 \mathrm{~m}$, and slightly decreasing toward the bottom to $56 \pm 3 \mu \mathrm{mol} \mathrm{kg}{ }^{-1}$. Moreover, the contribution due to the dissolution of cal- cium carbonate increases constantly from $2 \pm 3 \mu \mathrm{mol} \mathrm{kg}^{-1}$ at a depth of $500 \mathrm{~m}$ to $33 \pm 3 \mu \mathrm{mol} \mathrm{kg}-1$ at a depth of $3685 \mathrm{~m}$. The $C_{\mathrm{T}}^{\text {carb }}$ contributes half the $C_{\mathrm{T}}^{\mathrm{org}}$. The contribution of both the carbonate and the soft-tissue pumps to the inorganic carbon concentration at ESTOC can also be monitored via the ratio, $C_{\mathrm{T}}^{\text {carb }} / C_{\mathrm{T}}^{\text {org }}$ (Fig. 10). The ratio increases continuously from a value of 0.02 at $500 \mathrm{~m}$ to 0.53 at the bottom. The value of 0.45 at $3000 \mathrm{~m}$ indicates that $31 \%$ of the inorganic carbon production is related to the dissolution of calcium carbonate, while it becomes $35 \%$ at $3685 \mathrm{~m}$. These high values clearly indicate the old age of the lower NADW.

\subsection{Changes in the anthropogenic carbon}

Over the last few decades, there have been countless attempts to determine the anthropogenic part of the inorganic carbon exchange between the atmosphere and the ocean (e.g. Gruber et al., 1996; Sabine et al., 2004). The first attempts to estimate $C_{\mathrm{ANT}}$ from oceanic measurements were based on the back-calculation method proposed independently by Brewer (1978) and Chen and Millero (1979). Despite all of various efforts and methods, no clear conclusion has been reached as to which method is best after several comparative exercises (see more on Vázquez-Rodríguez et al., 2009). We have applied the carbon-based TrOCA method to our set of data which uses the semi-conservative parameter TrOCA (Tracer combining Oxygen, inorganic Carbon and total Alkalinity). A detailed description of the TrOCA approach is given in Touratier and Goyet (2004) and further improvements in Touratier et al. (2007), where $C_{\mathrm{ANT}}$ is calculated as the difference between current and pre-industrial TrOCA. The TrOCA approach assumes that below the mixed layer, the decomposition of organic matter follows a constant Redfield relationship and that today's air-sea $\mathrm{CO}_{2}$ disequilibrium is the same as in pre-industrial times. The estimated uncertainty for the TrOCA approach is about $7 \mu \mathrm{mol} \mathrm{kg}-1$ (Touratier et al., 2007).

Figure 11 depicts how the concentration of anthropogenic $\mathrm{CO}_{2}$ decreases with depth. Experimental values for each year were used to compute $C_{\mathrm{ANT}}$ and then were averaged for each sampling depth and plotted together with standard deviation. Below $3000 \mathrm{~m}, C_{\mathrm{ANT}}$ values tend to zero, implying that this may be considered the maximum depth they can reach at the ESTOC. The penetration depth at $3000 \mathrm{~m}$ is in close concordance with other studies reported previously for the North Atlantic (Sabine et al., 2004). The concentration of anthropogenic $\mathrm{CO}_{2}$ in the $150-200 \mathrm{~m}$ seawater, just below the average Winter mixed layer at ESTOC, is $57 \pm 4 \mu \mathrm{mol} \mathrm{kg}^{-1}$, slightly higher than the values presented by Sabine et al. (2004) of around $50 \mu \mathrm{mol} \mathrm{kg}{ }^{-1}$ for the North and Tropical Atlantic Ocean. The different methodologies used and the differences in the reference year, 1990-1998 versus 1995-2004, may account for the values observed. It is also to be observed that in the region of $1000-1500 \mathrm{~m}$, where the Mediterranean waters are located, $C_{\mathrm{ANT}}$ presents 


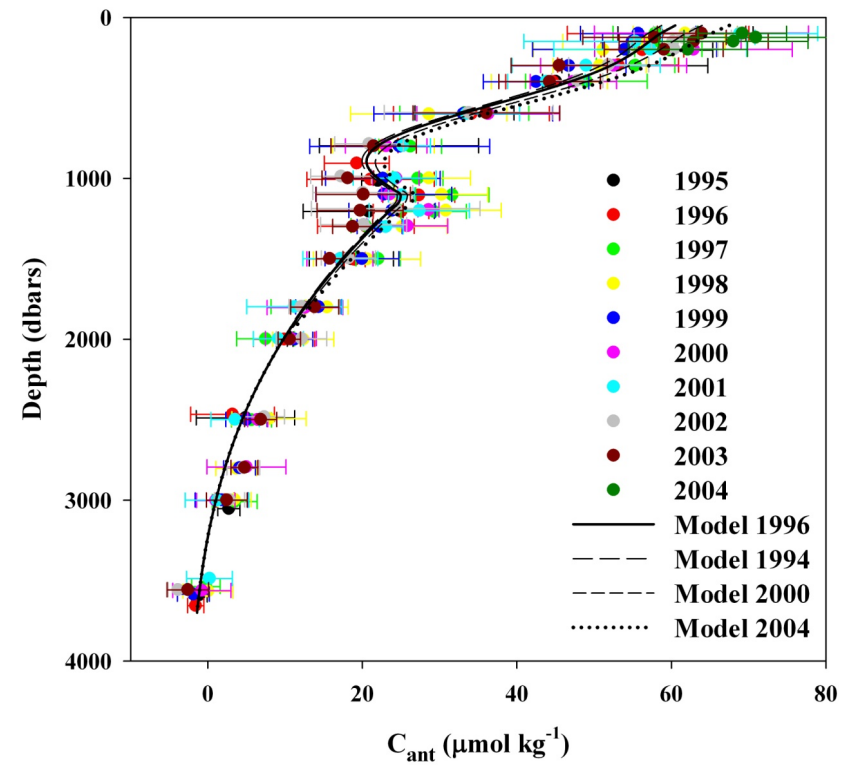

Fig. 11. The concentration of anthropogenic $\mathrm{CO}_{2}$ for the period 1995 to 2004, averaged for each year and sampling depths and plotted together with their standard deviation. A fitting order 5 polynomial function for the year 1996 is plotted together with predicted values for the years 1994, 2000 and 2004, assuming oceanic physical and biological conditions to be stable and the rate of anthropogenic $\mathrm{CO}_{2}$ increase given by the rate of $C_{\mathrm{T}}$ increase in Table 1 .

a relative maximum with values of $24 \pm 5 \mu \mathrm{mol} \mathrm{kg}^{-1}$. The concentrations of anthropogenic $\mathrm{CO}_{2}$ in the Mediterranean Sea at the time series station DYFAMED, and in the Strait of Gibraltar (Aït-Ameur and Goyet, 2006; Huertas et al., 2009; Touratier and Goyet, 2009) are much higher than those found in the Atlantic Ocean at the same depth. Values North of $35^{\circ} \mathrm{N}$ at the Iberian Peninsula in the region of $1000 \mathrm{~m}$ also present relative maximums over $30 \mu \mathrm{mol} \mathrm{kg}{ }^{-1}$ (Ríos et al., 2001), slightly higher than those at ESTOC and relating to the greater contribution of the MW to this area. Our results confirm that the Mediterranean Sea acts as a significant source of anthropogenic carbon to the Atlantic Ocean.

The $C_{\mathrm{ANT}}$ annually computed at ESTOC from 1995 to 2004 may be used to evaluate inter-annual trends. If the oceanic physical and biological conditions are assumed to be constant along the decade, the rate of $C_{\mathrm{T}}$ increase on any isopycnal surface should be the rate of the anthropogenic $\mathrm{CO}_{2}$ increase absorbed by the seawater. In surface seawater and as was indicated above, the $C_{\mathrm{T}}$ increased at a rate of $0.94 \pm 0.50 \mu \mathrm{mol} \mathrm{kg}^{-1} \mathrm{yr}^{-1}$, that is, $9.4 \mu \mathrm{mol} \mathrm{kg}{ }^{-1}$ over a decade, over the experimental error of estimate of $C_{\mathrm{T}}$. At $200 \mathrm{~m}$, with potential density $26.56 \pm 0.05$, the $C_{\mathrm{T}}$ increased at a rate of $0.81 \pm 0.40 \mu \mathrm{mol} \mathrm{kg}{ }^{-1} \mathrm{yr}^{-1}$ (Table 1). At higher densities, the relation between the depth and the potential density is relatively constant and the $C_{\mathrm{T}}$ (Table 1) increase at a rate over the error associated to the $C_{\mathrm{T}}$ determination in one decade in the first $1000 \mathrm{~m}$. However, the $C_{\mathrm{ANT}}$ de- termination presents an estimated error higher than the rate of increase of the $C_{\mathrm{T}}$, and any trend determined by using $C_{\text {ANT }}$ values is statistically insignificant. In the first $200 \mathrm{~m}$, the yearly average for $C_{\mathrm{ANT}}$ was found to increase at a rate of $0.85 \pm 0.6 \mu \mathrm{mol} \mathrm{kg} \mathrm{yr}^{-1}$, which is in the same range as the observed increase in the $C_{\mathrm{T}}$, but with a significant error in estimate. According to our series of data, over ten years are needed to unequivocally determine the anthropogenic carbon increase in this area.

Figure 11 also depicts a fitting order 5 polynomial function for the year 1996 (standard error of estimate, $5.65 \mu \mathrm{mol} \mathrm{kg}-1$ ), selected as a reference for our study. If we assume the rate of anthropogenic $\mathrm{CO}_{2}$ increase to be due to the $C_{\mathrm{T}}$ increase and the data given by Table 1 to be valid for the decade 1995-2004, the anthropogenic carbon can be computed for any other year. Inter-annual change is fitted to a polynomial equation as a function of depth $(z$ in $\mathrm{m})$

$$
\begin{aligned}
\Delta C_{\mathrm{T}}= & 0.94-1.34 \times 10^{-3} z+1.06 \times 10^{-6} z^{2} \\
& -5.51 \times 10^{-10} z^{3}+1.61 \times 10^{-13} z^{4}-1.86 \times 10^{-17} z^{5}
\end{aligned}
$$

that indicates a surface change per year of $0.94 \pm$ $0.05 \mu \mathrm{mol} \mathrm{kg}{ }^{-1}$ and is added to or subtracted from the values for the year 1996. The resulting lines clearly follow the evolution of the $C_{\mathrm{ANT}}$ observed at the ESTOC site. The total column inventory of anthropogenic $\mathrm{CO}_{2}$ was estimated to be $66 \pm 3 \mathrm{~mol} \mathrm{~m}^{-2}$ at the ESTOC site, after considering the average values at each depth over the decade studied. This value (the average for the period 1995-2004, that is the year 2000) is again around $6 \mathrm{~mol} \mathrm{~m}^{-2}$ higher than the value determined by Sabine et al. (2004) for the year 1994 using Gruber et al. (1996) $\Delta C^{*}$ methodology. However, it is within the estimated error indicated by these authors considering the uncertainties of anthropogenic $\mathrm{CO}_{2}$ estimates and mapping errors. However, our model fitting indicated that for the year 1994, the estimated column inventory of $C_{\mathrm{ANT}}$ is $61.3 \mathrm{~mol} \mathrm{~m}^{-2}$, similar to the value given by Sabine et al. (2004) at $30^{\circ} \mathrm{N}$ in the North Atlantic for the year 1994, of $60-61 \mathrm{~mol} \mathrm{~m}^{-2}$. The inventory for the year 2004 reached $70.0 \mathrm{~mol} \mathrm{~m}^{-2}$, in line with the $\mathrm{C}_{T}$ inter-annual trends presented in Table 1 (Eq. 11) and plotted on Fig. 11, indicating an increase of $0.84 \mathrm{~mol} \mathrm{~m}^{-2} \mathrm{yr}^{-1}$. These data indicate that the Eastern North Atlantic Ocean at the area where the ESTOC station is located presents an increasing content in excess $\mathrm{CO}_{2}$. At this area, ESTOC, as one of the longest carbon time series station, can be used as a reference point by which to monitor anthropogenic carbon changes in the Northeast Atlantic Sub-tropical gyre.

\section{Conclusions}

In this work, we have investigated the water column distribution of carbonate system variables in the Northeast Atlantic Sub-tropical after considering the data from 87 cruises to 
ESTOC from September 1995 to February 2004. The interannual variability for the carbon dioxide parameters was defined for 12 selected depths, clearly indicating significant changes over, at least, the first $1000 \mathrm{~m}$. The $C_{\mathrm{T}}$ increased at a rate of $0.87 \mu \mathrm{mol} \mathrm{kg}{ }^{-1} \mathrm{yr}^{-1}$ in the mixed layer, linked to an $f \mathrm{CO}_{2}$ increase of $1.7 \pm 0.7 \mu \mathrm{atm} \mathrm{\textrm {yr } ^ { - 1 }}$ in both the atmosphere and the ocean. Consequently, the ESTOC site has also become more acidic, with the $\mathrm{pH}_{\mathrm{T}}$ decreasing annually at a rate of $-0.0017 \pm 0.0003$ units $\mathrm{yr}^{-1}$ in the MLD, similar to what is expected from oceanic equilibration with increasing $\mathrm{CO}_{2}$ in the atmosphere. In addition, the carbonate ion concentrations and $\mathrm{CaCO}_{3}$ saturation states have also decreased over time. The $\Omega_{\text {cal }}$ over the first $100 \mathrm{~m}$ has decreased 0.2 units from an initial value in 1995 of $5.44 \pm 0.14$, whereas the $\Omega_{\text {arag }}$ moved from $3.55 \pm 0.09$ in 1995 to $3.4 \pm 0.08$ in 2004 . The $\Omega_{\text {arag }}$ rate of change is observed over the first $1000 \mathrm{~m}$, and if this rate is assumed to remain constant throughout this century, a value of around $2 \pm 0.1$ will be found in the surface waters of the ESTOC by 2100 and the $\Omega_{\text {arag }}$ profile will change its exponential decay with depth, to a homogenous layer of around $600 \mathrm{~m}$ with $\Omega_{\text {arag }}$ of $2 \pm 0.1$ and with values of $1.2 \pm 0.1$ at $1500 \mathrm{~m}$.

The vertical distribution of the carbonate system variables is affected by the water mass structure and, to a different extent, controlled by the production/decomposition of organic matter, formation/dissolution of carbonates, and the differences in respective pre-formed values. The $N A_{\mathrm{T}}$ increases with depth mainly as a result of the pre-formed values that overcompensate the consumption of $A_{\mathrm{T}}$ during organic decomposition, remaining constant over the top $200 \mathrm{~m}$ of water column, whereas the carbonate dissolution accounts for the constant increase in $N A_{\mathrm{T}}$ under $400 \mathrm{~m}$. For the $N C_{\mathrm{T}}$, the total inorganic carbon increase is related similarly to the increase in both the pre-formed values and the remineralization of organic matter over the first $500 \mathrm{~m}$. The $C_{\mathrm{T}}^{\text {org }}$ contribution is maximum at around $900-1000 \mathrm{~m}$. The dissolution of calcium carbonate increases constantly from depth of $500 \mathrm{~m}$ to $3685 \mathrm{~m}$, but is only half the contribution of the $C_{\mathrm{T}}^{\text {org }}$. At $3000 \mathrm{~m}, 30 \%$ of the inorganic carbon production is related to the dissolution of calcium carbonate, becoming $35 \%$ at $3685 \mathrm{~m}$.

The concentration of anthropogenic $\mathrm{CO}_{2}$ in the first 150 $200 \mathrm{~m}$ of seawater for the reference year 2000 was $57 \pm$ $4 \mu \mathrm{mol} \mathrm{kg}{ }^{-1}$ whereas the penetration depth was $3000 \mathrm{~m}$. Ten years of study are not enough to unequivocally define inter-annual trends. However, surface values presented a statistically significant rate of $C_{\mathrm{ANT}}$ increase of $0.85 \pm$ $0.6 \mu \mathrm{mol} \mathrm{kg} \mathrm{gr}^{-1}$. If oceanic physical and biological conditions are assumed to be steady during this decade, we have provided a way to compute inter-annual changes over the water column by applying the vertical rate of change of the $C_{\mathrm{T}}$ to the $C_{\mathrm{ANT}}$ profile for a reference year. The total column inventory of anthropogenic $\mathrm{CO}_{2}$ for the decade (reference year 2000 ) is $66 \pm 3 \mathrm{~mol} \mathrm{~m}^{-2}$. The model fitting indicates that the column inventory of $C_{\mathrm{ANT}}$ increased from $61.3 \mathrm{~mol} \mathrm{~m}^{-2}$ in the year 1994 to $70.0 \mathrm{~mol} \mathrm{~m}^{-2}$ in 2004 . The general concordance of these results with others at $30^{\circ} \mathrm{N}$ in the North Atlantic confirms that the ESTOC site can be used as a reference to monitor anthropogenic carbon changes in the Northeast Atlantic Sub-tropical gyre.

Acknowledgements. This work received the support of the Spanish Ministry of Science and Innovation (Ministerio de Ciencia e Innovación), the MOMAC project (CTM2008-05914) and from the EUROSites project FP7/2007-2013 under the grant agreement no. 202955. Over the years, several other projects have provided partial assistance in carrying out the research: the CANIGO project (MAS3-CT96-0060), the Ministerio de Ciencia y Tecnología, the "Proyecto FLUCAN" (2002-01548) and the European Project CARBOOCEAN 2005-2009, CN 511176-2. The authors thank all the participants in the cruises, together with the masters, officers and crew of the research vessels "Taliarte", "Meteor", "Victor Hensen" and "Poseidon", and the Spanish Navy in Las Palmas who have lent their support to the cruises over the years. We would also like to thank M. Hart for correcting the English version. We are grateful to two anonymous reviewers for their constructive and critical comments.

Edited by: J. Middelburg

\section{References}

Ait-Ameur, N. and Goyet, C.: Distribution and transport of natural and anthropogenic $\mathrm{CO}_{2}$ in the Gulf of Cádiz, Deep-Sea Res., II, 53, 1329-1343, 2006.

Anderson, L. A. and Sarmiento, J. L.: Redfield ratios of remineralization determined by nutrient data analysis, Global Biogeochem. Cycles, 8, 65-80, 1994.

Bates, N. R.: Interannual variability of oceanic CO2 and biogeochemical properties in the western North Atlantic subtropical gyre, Deep Sea Res., Part II, 48, 1507-1528, 2001.

Bates, N. R.: Interannual variability of the oceanic CO2 sink in the subtropical gyre of the North Atlantic Ocean over the last two decades, J. Geophys. Res., 112, C09013, doi:10.1029/2006JC003759, 2007.

Bates, N. R., Michaels, A. F., and Knap, A. H.: Seasonal and interannual variability of the oceanic carbon dioxide system at the U.S. JGOFS Bermuda Atlantic Time-series Site, Deep Sea Res., Part II, 43, 347-383, 1996.

Brewer, P. G.: Direct observation of the oceanic $\mathrm{CO}_{2}$ increase. Geophys. Res. Lett., 5, 997-1000, 1978.

Brix, H., Gruber, N., and Keeling, C. D.: Interannual variability of the upper ocean carbon cycle at station ALOHA near Hawaii, Global Biogeochem. Cycles, 18, GB4019, doi:10.1029/2004GB002245, 2004.

Chen, C. T. A. and Millero, F. J.: Gradual increase of oceanic $\mathrm{CO}_{2}$, Nature, 277, 205-206, 1979.

Chou, W. C., Sheu, D. D., Chen, C. T. A., Wang, S. L., and Tseng, C. M.: Seasonal variability of carbon chemistry at the SEATS time-series site, northern South China Sea between 2002 and 2003, Terr. Atmos. Oceanic Sci., 16, 445-465, 2005.

Chou, W. C., Sheu, D. D., Lee, B. S., Tseng, C. M., Chen, C. T. A., Wang, S. L., and Wong, G. T. F.: Depth distributions of alkalinity, 
$\mathrm{TCO}_{2}$ and $\delta^{13} \mathrm{C}_{\mathrm{TCO} 2}$ at SEATS time-series site in the northern South China Sea, Deep-Sea Res., II, 54, 1469-1485, 2007.

Cianca, A., Helmke, P., Mouriño, B., Rueda, M. J., Llinás, O., and Neuer, S.: Decadal analysis of hydrography and in situ nutrient budgets in the western and eastern North Atlantic subtropical gyre, J. Geophys. Res., 112, C07025, doi:10.1029/2006JC003788, 2007.

Dickson, A. G. and Millero, F. J.: A comparison of the equilibrium constants for the dissociation of carbonic acid in seawater media, Deep-Sea Res., 34, 1733-1743, 1987.

Dore, J. E., Lukas, R., Sadler, D. W., Church, M. J., and Karl, D. M.: Physical and biogeochemical modulation of ocean acidification in the central North Pacific, PNAS, 106(30), 12235-12240, 2009.

Friis, K., Körtzinger, A., and Wallace, D. W. R.: The salinity normalization of marine inorganic carbon chemistry data, Geophys. Res. Lett., 1085, 33(2), doi:10.1029/2002GL015898, 2003.

Friis, K., Najjar, R. G., Follows, M. J., Dutkiewicz, S., Körtzinger, A., and Johnson, K. M.: Dissolution of calcium carbonate: observations and model results in the subpolar North Atlantic, Biogeosciences, 4, 205-213, doi:10.5194/bg-4-205-2007, 2007.

Gislefoss, J. S., Nydal, R., Slagstad, D., Sonninen, E., and Holmén, K.: Carbon time series in the Norwegian Sea, Deep-Sea Res., I, 45, 433-460, 1998.

Gonzalez-Dávila, M., Santana-Casiano, J. M., Rueda, M. J., Llinás, O., and Gonzalez-Dávila, E. F.: Seasonal and interannual variability of seasurface carbon dioxide species at the European Station for Time Series in the Ocean at the Canary Islands (ESTOC) between 1996 and 2000, Global Biogeochem. Cycles, 17(3), 1076, doi:10.1029/2002GB001993, 2003.

González-Dávila, M., Santana-Casiano, J. M., and GonzálezDávila, E. F.: Interannual variability of the upper ocean carbon cycle in the northeast Atlantic Ocean, Geophys. Res. Lett., 34, L07608, doi:10.1029/2006GL028145, 2007.

González-Dávila, M., Santana-Casiano, J. M., and Ucha, I. R.: Seasonal variability of $f \mathrm{CO}_{2}$ in the Angola-Benguela región, Prog. Oceanog., 83, 124-133, 2009.

Gruber, N., Sarmiento, J. L., and Stocker, T. F.: An improved method for detecting anthropogenic $\mathrm{CO} 2$ in the oceans. Global Biogeochemical Cycles, 10, 809-837, 1996.

Huertas, I. E., Ríos, A. F., García-Lafuente, J., Makaoui, A., Rodríguez-Gálvez, S., Sánchez-Román, A., Orbi, A., Ruíz, J., and Pérez, F. F.: Anthropogenic and natural $\mathrm{CO}_{2}$ exchange through the Strait of Gibraltar, Biogeosciences, 6, 647-662, doi:10.5194/bg-6-647-2009, 2009.

Keeling, C. D., Brix, H., and Gruber, N.: Seasonal and longterm dynamics of the upper ocean carbon cycle at Station ALOHA near Hawaii, Global Biogeochem. Cycles, 18, GB4006, doi:10.1029/2004GB002227, 2004.

Lewis, E. D. and Wallace, W. R.: Program developed for $\mathrm{CO}_{2}$ system calculations. Report 105, Oak Ridge National. Laboratory, US Department of Energy, Oak Ridge, Tenn, 1998.

Llinás, O., Rodríguez de León, A., Siedler, G., and Wefer, G.: ESTOC data report 1995- 1996, Inf. Téc. 7, 152 pp., Inst. Canario Cienc. Mar., Telde, Canary Islands, 1999.

Llinás, O., Rueda, M., Pérez-Marrero, J., Pérez-Martel, E., Santana, R., Villagarcía, M., Cianca, A., Godoy, J., and Maroto, L.: Variability of the Antartic Intermediate Waters in the northern Canary box, Deep-Sea Res., II, 49, 3441-3453, 2002.

Machín, F., Hernández-Guerra, A., and Pelegrí, J. L.: Mass fluxes in the Canary basin, Prog. Oceanogr., 70, 416-447, 2006.

Mehrbach, C., Culberson, C. H., Hawlay, J. E., and Pytkowicz, R. M.: Measurement of the apparent dissociation constants of carbonic acid in seawater at atmospheric pressure, Limnol. Oceanogr., 18, 897-907, 1973.

Milliman, J. D., Troy, P. J., Balch, W. M., Adams, A. K., Li, Y. H., and Mackenzie, F. T.: Biological mediated dissolution of calcium carbonate above the chemical lysocline, Deep-Sea Res. I, 46, 1653-1669, 1999.

Mintrop, L., Pérez, F. F., González Dávila, M., Körtzinger, A., and Santana- Casiano, J. M.: Alkalinity determination by potentiometry: intercalibration using three different methods, Cien. Mar., 26, 23-37, 2000.

Neuer, S., Cianca, A., Helmke, P., Freudenthal, T., Davenport, R., Meggers, H., Knoll, M., Santana-Casiano, J. M., GonzálezDavila, M., Rueda, M. J., and Llinás, O.: Biogeochemistry and hydrography in the eastern subtropical North Atlantic gyre: Results from the European time-series station ESTOC, Prog. Oceanogr., 72, 1-29, 2007.

Olafsson, J., Olafsdottir, S. R., Benoit-Cattin, A., Danielsen, M., Arnarson, T. S., and Takahashi, T.: Rate of Iceland Sea acidification from time series measurements, Biogeosciences, 6, 26612668, doi:10.5194/bg-6-2661-2009, 2009.

Olafsson, J., Olafsdottir, S. R., Benoit-Cattin, A., and Takahashi, T.: The Irminger Sea and the Iceland Sea time series measurements of sea water carbon and nutrient chemistry 1983-2008, Earth Syst. Sci. Data, 2, 99-104, doi:10.5194/essd-2-99-2010, 2010.

Pérez, F. F., Mintrop, L., Llinás, O., González-Dávila, M., Castro, C., Koertzinger, A., Santana-Casiano, M., Alvarez, M., and Ríos, A. F.: Mixing analysis of nutrients, oxygen and inorganic carbon in the Canary Islands region, J. Mar. Syst., 28, 183-201, 2001.

Pérez, F. F., Álvarez, M., and Ríos, A. F.: Improvements on the back-calculation technique for estimating anthropogenic $\mathrm{CO}_{2}$, Deep-Sea Res., I, 49, 859-875, 2002.

Ríos, A. F., Pérez, F. F., and Fraga, F.: Long-term (1977/1997) measurements of carbon dioxide in the Eastern North Atlantic: evaluation of anthropogenic input, Deep-Sea Res., II, 48, 2227-2239, 2001.

Sabine, C. L., Feely, R. A., Gruber, N., Key, R. M., Lee, K., Bullister, J. L., Wanninkhof, R., Wong, C. S., Wallace, D. W. R., Tilbrook, B., Millero, F. J., Peng, T.-H., Kozyr, A., Ono, T., and Rios, A. F.: The oceanic sink for anthropogenic $\mathrm{CO}_{2}$, Science, 305, 367-371, 2004.

Santana-Casiano, J. M., González-Dávila, M., and Laglera, L. M.: Carbon dioxide system in the Canary Region during October 1995, Scientia Mar., 65, 41-49, 2001.

Santana-Casiano, J. M., González-Dávila, M., Rueda, M. J., Llinás, O., and González-Dávila, E. F.: The interannual variability of oceanic $\mathrm{CO} 2$ parameters in the northeast Atlantic subtropical gyre at the ESTOC site, Global Biogeochem. Cycles, 21, GB1015, doi:10.1029/2006GB002788, 2007.

Skjelvan, I., Falck, E., Rey, F., and Kringstad, S. B.: Inorganic carbon time series at Ocean Weather Station $M$ in the Norwegian Sea, Biogeosciences, 5, 549-560, doi:10.5194/bg-5-549-2008, 2008.

Solomon, S., Qin, D., Manning, M., Alley, R. B., Berntsen, T., et al.: Technical Summary, in: Climate Change 2007: The Physical Science Basis, Contribution of Working Group I to the Fourth 
Assessment Report of the Intergovernmental Panel on Climate Change, edited by: Solomon, S., Qin, D., Manning, M., Chen, Z., Marquis, M., Averyt, K. B., Tignor M., and Miller, H. L., Cambridge University Press, Cambridge, UK and New York, NY, USA, 2007.

Touratier, F. and Goyet, C.: Applying the new TrOCA approach to assess the distribution of anthropogenic $\mathrm{CO}_{2}$ in the Atlantic Ocean, J. Mar. Syst., 46, 181-197, 2004.

Touratier, F., Azouzi, L., and Goyet, C.: CFC-11, $\Delta{ }^{14} \mathrm{C}$ and ${ }^{3} \mathrm{H}$ tracers as a means to assess anthropogenic $\mathrm{CO}_{2}$ concentrations in the ocean, Tellus, 59B, 318-325, 2007.

Touratier, F. and Goyet, C.: Decadal evolution of anthropogenic $\mathrm{CO}_{2}$ in the northwestern Mediterranean Sea from the mid-1990s to the mid-2000s, Deep-Sea Res., I, 56, 1708-1716, 2009.

Tsurushima, N., Nojiri, Y., Imai, K., and Watanabe, S.: Seasonal variations of carbon dioxide system and nutrients in the surface mixed layer at station KNOT $\left(44^{\circ} \mathrm{N}, 155^{\circ} \mathrm{E}\right)$ in the subarctic western North Pacific, Deep-Sea Res., II, 49, 5377-5394, 2002.

Turley, C.: The other $\mathrm{CO}_{2}$ problem, open Democracy. http://www.acamedia.info/sciences/sciliterature/globalw/ reference/carolturley.html, 2005.

Vázquez-Rodríguez, M., Touratier, F., Lo Monaco, C., Waugh, D. W., Padin, X. A., Bellerby, R. G. J., Goyet, C., Metzl, N., Ríos, A. F., and Pérez, F. F.: Anthropogenic carbon distributions in the Atlantic Ocean: data-based estimates from the Arctic to the Antarctic, Biogeosciences, 6, 439-451, doi:10.5194/bg-6-4392009, 2009.
Wakita, M., Watanabe, S., Watanabe, Y. W., Ono, T., Tsurushima, N., and Tsunogai, S.: Temporal change of dissolved inorganic carbon in the subsurface water at Station KNOT $\left(44^{\circ} \mathrm{N}, 155^{\circ} \mathrm{E}\right)$ in the western North Pacific subpolar region, J. Oceanogr., 61(1), 129-139, 2005.

Wanninkhof, R. and Thoning, K.: Measurement of fugacity of $\mathrm{CO}_{2}$ in surface water using continuous and discrete sampling methods, Mar. Chem., 44, 189-204, 1993.

Wanninkhof, R., Doney, S. C., Peng, T. H., Bullister, J. L., Lee, K., and Feely, R. A.: Comparison of methods to determine the anthropogenic $\mathrm{CO}_{2}$ invasion into the Atlantic Ocean, Tellus, 51B, 511-530, 1999.

Winn, C., Li, Y.-H., Mackenzie, F. T., and Karl, D. M.: Rising surface ocean dissolved inorganic carbon at the Hawaii Ocean Time-series site, Mar. Chem., 60, 33-47, 1998.

Wong, C. S., Whitney, F. A., Crawford, D. W., Iseki, K., Matear, R. J., Johnson, W. K., and Page, J. S.: Seasonal and interannual variability in particle fluxes of carbon, nitrogen and silicon from time series of sediment traps at Ocean Station P, 1982-1993: Relationship to changes in subarctic primary productivity, Deep Sea Res., Part II, 46, 2735-2760, 1999. 